\title{
THE ADMINISTRATION OF JUSTICE AND THE CONCEPT OF LEGALITY IN EAST GERMANY*
}

\author{
OTTO KIRGHHEIMER $\dagger$
}

WITHIN the Soviet orbit of Eastern European states, the East German Democratic Republic (Deutsche Demokratische Republik or DDR) occupies a rather atypical place. ${ }^{1}$ The policy of its administration serves a dual purpose. First, it aims at speedy integration with the other Communist-directed countries and furthers as much social change as that process requires. In addition, it is expected to pave the way for the eventual absorption of all Germany into the Eastern world. Hence, the pace of integration into the Eastern bloc is not simply conditioned by the prevailing economic and social situation, but is also subject to counterchecks in that a kind of ideological competition with Western Germany's Federal Republic somehow remains on the agenda. ${ }^{2}$

:This article will constitute a chapter in a forthcoming book, Politics and the Adninistration of Justice. The support of the Rockefeller Foundation for this study is gratefully acknowledged. A. R. Gurland rendered invaluable assistance in the preparation of the section on Doctrinal Gyrations by undertaking to select the original Russian texts otherwise accessible to the author only in so far as they have been translated.

$\dagger$ Professor of Political Science, Graduate Faculty of Political and Social Science, The New School for Social Research.

1. For a recent study of the legal system of Soviet Russia itself, see Berman, Soviet Law Reform-Dateline Moscow 1957, 66 Y ALE L.J. 1191 (1957). This article, especially valuable for its searching exploitation of colloquial statements by Soviet legal authorities, rests on the implied thesis that Soviet juridical performance somehow may be traced to a dichotomy between legality and force, and that their respective provinces are dependent on the pressures and circumstances of the moment. In the light of this thesis, the present period-with inevitable deviations and countercurrents-could be considered as one of expanding legality, a development made possible by the fact that "a totalitarian system of government which operates by despotic methods in politics can create a legal order which operates with considerable stability and independence in matters considered nonpolitical." Id. at $1212 \mathrm{n} .75$.

But whether Professor Berman's dichotomy, applicable as it might be to other systems, is a meaningful point of departure for analyzing the Communist concept of legality and the functioning of its judicial machinery, is not so clear. Legality (zakonnost') in Communist parlance has a complementary or possibly counterconcept: partiinost." This untranslatable term denotes both the party-subservient quality of ideas and institutions and the party allegiances of men.

Understanding how the legality-force or political-nonpolitical dichotomy relates to the presuppositions underlying the interplay between legality and partiinost' is fundamental to comprehending the Communist "rule of law." This Article will study some facets of that relationship under the judicial administration of a territory which, since the end of World War II, has formed an integral part of the Communist political system.

2. The curtain separating the two parts of Germany is not tightly drawn. Private individuals constantly cross the border for visits; citizens of East Germany have been 
Eastern integration and Western rivalry have produced contradictory effects. No continuous sequence of bloody purges in the ranks of the ruling party, after the pattern of the USSR and the majority of its satellites, has cramped the DDR's style; no show trials have announced a prefabricated alternative reality; neither intraparty fighting over policy nor repercussions of party shifts in Russia have duplicated Moscow trials, a fact repeatedly emphasized, with caution but not without satisfaction, by Frau Hilde Benjamin, now at the helm of the DDR Ministry of Justice. ${ }^{3}$ Nevertheless, dealing with a population somewhat less submissive than that of some neighboring countries, DDR rulers have at times felt less secure and have acted more harshly than their colleagues abroad. Whenever the screws are tightened, there is a great deal more hesitation about releasing them.

In spite of heavy borrowing from Soviet concepts of the judicial process, conditions peculiar to the Eastern Zone have impressed upon the DDR judicial apparatus certain traits which give it a special flavor. The absence of what may be called totalitarian extremism and, in contrast, an aversion to liberalizing experiments help illuminate the political problems that inhere in any Sovietized administration of justice. When the effects of both inordinately severe and lenient tendencies are lacking, the typical stands out in bold relief.

\section{The Institutions of Justice}

Although the present organization of the dispensers and administrators of justice in the DDR dates from the autumn of $1952, \overline{5}$ the statutes of that year only elaborate patterns which were discernible long before. As early as 1950 , various postwar administrative organs had been dispensed with ${ }^{6}$ and their functions transferred to the Ministry of Justice. A new High Court and an attorney

registering protest votes against the Government by transferring their domicile from the jurisdiction of the Communist bosses to the greener pastures of the West German Federal Republic. All this is not without influence on the DDR administration.

3. For the most recent example, see Editorial, Ergebnisse der Diskussion 1leber die Amwendung der STPO, 11 NEUE Justiz [hereinafter cited as N.J.] 601 (1957).

4. Borrowing is made easy. An official monthly, Rechtswissenschaftlicher Informationsdienst, prints most of the important Soviet (and other orbit) legal discussions; a number of Soviet textbooks of law have been translated. Scholars are required to absorb Soviet concepts and judges and prosecutors also may take notice. Occasionally embarrassing incidents arise when a German translation comes off the press after the Soviet authorfor example, Andrey Yao Vishinskii-has just been removed from the pedestal.

5. The two main statutes, the one on court organization (Gerichtsverfassungsgesetz [hereinafter cited as G.V.G.]), [1952] Gesetzblatt der D.D.R. [hereinafter cited as G.B.D.D.R.] 983, and the Code of Criminal Procedure [hereinafter cited as C.C.P.], [1952] G.B.D.D.R. 996, carry the date of October 2, 1952; the statute on the organization of the Prosecutor's Office (Staatsanwaltschaftsgesetz [hereinafter cited as S.A.S.]) antedates them half a year, carrying the date of May 23, 1952, [1952] G.B.D.D.R. 408.

6. They were formally dissolved together with the state governments and state parliaments by the "Law on the Further Democratization of the Organization and Working Conditions of Public Bodies in the States of the D.D.R." of July 23, 1952, [1952] G.B.D.D.R. 613. 
general's office for the whole republic had been established as far back as 1949, when the state was permitted to take its final shape. ${ }^{7}$ By 1952, the two principal administrative agencies, the Ministry of Justice and the Office of the Attorney General, ${ }^{8}$ functioning separately, had clearly become the central focus for directing activities in the legal field. Lnlike the usual ministry of justice found in continental democracies, these two agencies assumed much more than the usual tasks of selecting judges and prosecutors, instructing the prosecuting staff, doing part of the housekeeping job for the courts, and functioning as drafting uffice for nonspecialized legislation. They became responsible for the satisfactory functioning of the judicial order. They are the guarantors of the intellectual content of the judiciary's output. They ensure that the courts will deliver judgments in harmony with the goals of the administration. ${ }^{9}$ In explaining the organization of the various tribunals, in delineating their hierarchical relationship, this role must constantly be kept in mind. The judicial hierarchy of the East German Republic does not terminate in its highest tribunal, the High Court, but extends beyond it and culminates in the two coordinated administrative organs, the Ministry of Justice and the Office of the Attorney General. ${ }^{10}$ Both have more or less formalized means at their disposal for influencing the disposition of individual cases and directing the course of future legal decisions.

The lowest basic tribunal is the county court, with at least one for each of the 217 counties. Large centers of population may have as many county courts as there are city districts. Such a court consists of one professional judge and two lay assessors, ${ }^{11}$ and has original jurisdiction over all criminal cases except those specifically assigned to other courts. ${ }^{12}$ It has full jurisdiction over civil suits, regardless of the amount involved, with the exception of controversies involving property of pullic bodies in which the amount at issue exceeds DMI $3,000 .^{13}$

7. Lan of Dec. 8. 1949, [1949] G.B.D.D.R. 111.

8. Whilk the Minister of Justice holds cabinet rank, the Attorney General is elected iur a fixed five-year term by the People's Chamber, S.A.S. \$ 3; however, this is a minor difference since the Attorney General has no superior other than the Council of Ministers, S.A.S. $\$ 1 ; \S 16(2)$ establishes his right to participate in the sessions of the Council of Ministers.

9. However, in one important field the Ministry of Justice has had to relinquish jurisdiction altogether. The prison services originally in its bailiwick passed into the hands of the Ministry of the Interior in 1950. Decree of Nov. 16, 1950, [1950] G.B.D.D.R. 1165, now codified in C.C.P. $\$ 336(1)$. The Attorney General's office exercises some general control function over the execution of punishment and the pertinent services.

10. The point is hardly controversial. It was forcefully repeated recently when Hilde Benjamin, the incumbent Minister of Justice, fought attempts to follow recent Soviet patterns of decentralization in the administration of justice. Benjamin, Akiuelle Fragen der Gerichtsorganisation, in StAAT UNd ReCht IM Lichte des gRossen OKTOBER 189 (1957).

11. G.V.G. $\S 43(1)$.

12. G.V.G. § 41(1).

13. G.V.G. $\S 42$. However, as now authorized by G.V.G. $\S 9$, access to the courts has been closed in a number of important controversies: lawsuits between "people's" enterprises belong before the State Contract Commission, Decrees of Dec. 6, 1951, [1951] G.B.D.D.R. 1143, June 11, 1953, [1953] 2 G.B.D.D.R. 854; damage claims against the state so far are not 
Registration of land titles, business firms and other associations, and guardianship and orphans' affairs, traditionally handled by the local court, have, however, been transferred to administrative agencies. Even so, the county courts handle most of the DDR's legal business. Ninety-three per cent of all criminal and ninety-nine per cent of all civil cases are tried in these courts. ${ }^{14}$

Next in line are fourteen district courts which exercise both original and appellate jurisdiction. In civil matters, they function mostly as courts of appeal. ${ }^{11}$ Their original criminal jurisdiction embraces crimes against the DDR, murder, and aggravated forms of economic crimes; the prosecutor may also upgrade other offenses and bring them before these tribunals. ${ }^{16}$ As appellate courts, they handle protests-that is, the prosecution's appeals-and defendants' appeals from county court judgments. ${ }^{17}$ Ordinarily, a district court sits as a division composed of one full-time judge and two lay assessors in cases of original jurisdiction and three full-time judges in appellate cases. ${ }^{18}$ Each of the fourteen district courts has a president who may in his discretion preside orer any case. ${ }^{10}$ Otherwise, the distribution of cases among the judges and divisions remains in the hands of each court's administrative unit. This unit leads an existence apart from the judicial members; it receives its cues from and owes obedience to the Ministry of Justice.

The High Court was established in 1949. After 1953, when its most colorful and energetic member, Frau Benjamin, surrendered her job as vice president of the court to become Minister of Justice, the court settled back to elaborate the details of the official legal program and ceased to participate in charting the DDR's overall legal course. Within its present framework, it still fulfills an essential role : it transmits to the lower courts the messages of the administrative agencies of justice. A given message may concern the introduction of a totally new program or the rectification of some isolated but symptomatic mistake spotted by the Ministry or the Attorney General's office. In this role, the High Court neither advances governmental policy nor lags far behind it. Loyally following official gyrations, the court tries to keep in line with changing requirements.

This highest court has both original and appellate jurisdiction. The field of

dealt with in any court; nor can the question of personal liability of the functionary involved be established in court proceedings. Some administrations grant a certain amount of indemnity on the basis of considerations of individual need. For a limited program of reopening access to the courts, see Schreier, Gedanken an einer gesetzlichen Regelung der Staatshaftung, 12 N.J. 195-98 (1958).

14. The figures are given by Hilde Benjamin; Aktuelle Fragen der Gerichtsorganisation, in StaAt und Recht im Lichte des Grossen Oktober 203 (1957).

15. Original suits against People's Enterprises, even though admissible, would at present lead to no practical result, as judgments could only be enforced with the consent of a division of the Ministry of Interior.

16. G.V.G. § $49(1)$.

17. G.V.G. $\$ 49(2)$.

18. G.V.G. $\$ \S 51(1),(3)$.

19. G.V.G. $\S 51(4)$. 
original jurisrliction over criminal cases is not determined in advance by the law, but on an $a d$ hoc basis by the Attorney General. ${ }^{20}$ As an appellate tribunal, the High Court considers protests, appeals and complaints against decisions issued by the district courts sitting as courts of original jurisdiction. ${ }^{21}$ The DDR thus has abolished the possibility of carrying appeals based on points of law through two judicial levels-a long-standing but by no means uncontroversial German tradition. Instead, it opens for the State, but only for the State, a new channel of attack upon final judgments. Borrowing from the Soviet system and the criminal procedure of the Third Reich, the East German Republic has instituted an extraordinary appeal. Both the Attorney General and the President of the High Court may bring any civil or criminal case before a plenary meeting of the court ${ }^{22}$ within a year ${ }^{23}$ from the date final judgment has been issued, whether by a lower court or by a three-judge division of the High Court itself. Such an extraordinary appeal, styled "cassation," may be based on a simple error of law or on an allegation that the attacked decision is "fundamentally incorrect so far as the sentencing is concerned." 24 The proceedings upon extraordinary appeal usually are conducted in great haste, and rarely exhaust the four-week limit provided for them in the code of criminal procedure. $^{25}$ The defendant, though permitted to be represented, is a passive object of, rather than a participant in, the proceedings. ${ }^{26}$ Frequently, the court will exercise its prerogative to enter a final judgment rather than send the case back to a lower tribunal.

From the viewpoint of the Government, the extraordinary appeal has a major arlvantage. By preserving the immutability of final judgments, the legal system of the DDR theoretically allows discrete problems to be settled in a manner which might not conform to the ever-shifting policies which characterize Communist regimes. The extraordinary appeal reduces the inconvenience that might arise from such a situation. No decision of any consequence can ever be established as a precedent unless it conforms to the official policy of the day. And, since every important High Court decision is instantly brought to the attention of judges at all levels, lower courts are quick to apply the doctrines enunciated by the High Court. Inasmuch as no case has been found in which the High Court refused to follow the policy directives of the Attorney General, that court is readily seen to provide the principal means of transmitting policy decisions from the government to the judiciary.

20. G.V.G. $\$ 55(1) 1$.

21. G.V.G. $\S 55(1) 2(a)$ :

22. In the USSR the extraordinary appeal, until the recent reform, has not been dependent on observation of a time limit; hence, in contrast to DDR decisions, Soviet judgments heretofore lacked the character of finality. For description of the USSR practice, see Governament, Law and Courts in the Soviet Union and in Eastern Europe 539 \& app. (Gsovski \& Grzbowski ed., in press).

23. G.V.G. $\$ \S 55(1) 3,56$.

24. C.C.P. $\S \S 301(2 \mathrm{a}),(2 \mathrm{~b})$.

25. C.C.P. $\$ 309(3)$.

26. C.C.P. $\$ 308$. 
The plenary assembly of the High Court exercises yet another, more farreaching, prerogative. Upon a motion by its president or the Attorney General or the Minister of Justice, it may issue directives of a general nature in the interest of unified application of the law. ${ }^{27}$ To date, twelve of these directives. binding on all courts, have been published. Some of them are simply authoritative interpretations of existing legislative enactments. ${ }^{28}$ Others have. by implication, abrogated existing legislation. In this category belong directives two and three of October 28 and 31, 1953, rendering inapplicable the penal provisions of certain statutes designed to protect the People's property and domestic German trade. ${ }^{29}$ The less severe strictures of pre-existing law were thus partially re-established. Both of these directives came at a time when the DDR government, impressed with the extent of popular disaffection shown in the June 1953 uprising, was eager to make a popular gesture. ${ }^{3 n}$

Whether amending previous legislation issued via normal enactment, or establishing new law, ${ }^{31}$ or implementing existing statutes, the High Court exercises delegated legislative power by setting general rules for an indeterminate number of cases. Both the issuance and revocation ${ }^{32}$ of norms is performed in

27. G.V.G. § 58 .

28. Here, for example, belongs Directive No. 9 concerning paragraph 8 of the divorce decree of 1955, issued July 1, 1957, reprinted in 11 N.J. 441 (1957), which sets out the preferred interpretation of a loosely worded provision, the indeterminate concepts of which allowed for a great degree of discretion in applying the decree to concrete situations.

29. Reprinted in the official edition of the penal code, STRAFGESETZBUCH DER DEVTSCHEN DenOKRatischen Republik 200 (1956).

30. More recently, Directive No. 7 of Nov. 20, 1956, [1956] G.B.D.D.R. 425, has changed article 11 of the decree on dismissal protection of June 7, 1951, [1951] G.B.D.D.R. 550, by introducing a new prerequisite for validity of employment dismissals: simultaneity of trade union confirmation of dismissal and written dismissal notice from the employer. See, Langner, Habcn dic Richtlinien des Obersten Gerichts rueckairkende Kraft?, 11 N.J. 624 (1957).

31. However, a number of directives pertain to new fields, where incipient, and at times conflicting, practices existed without benefit of a recognizable body of statutory law. This may have been due either to the novelty of the field (for example, Directive No. 6 setting out definite rules for the use and evaluation of blood typing in paternity cases, reprinted in 9 N.J. 447 (June 29, 1955)), or to the legislators' neglect to deal with more detailed problems, an especially prevalent failing in procedural fields. See, e.g., Directive No. 10 of July 1,1957 , setting out procedures in implementation of the decree handling divorce proceedings of Feb. 7, 1956, [1956] G.B.D.D.R. 145, reprinted in 11 N.J. 445 (1957), and the most recent Directive No. 12 issued April 28, 1958, 12 N.J. 317 (1958), giving detailed instructions on the proceedings to be followed in the application of C.C.P. \& 268. This provision concerns the pursuit of damage claims against a defendant by way of supplementary proceedings before the same court in which the criminal case is pending.

32. Directive No. 1 was revoked by a curt announcement from the High Court on April 30, 1956, 10 N.J. 263 (1956). The directive of April 29, 1953 concerned the prerequisites for remittance of sentences according to C.C.P. $\S 346$. Defending the High Court against criticism in regard to this removal procedure, the vice president of the court pointed out that this way of proceeding had been necessitated by the need to release prisoners beyond the frame of the normal application of $\$ 346$ in the "interest of the relaxation of the international situation." Ziegler, Zur Kritik am Obcrstcn Gericht, 
close liaison with, and at times at the immediate demand of, the executive organs. The unwillingness of Communist doctrine to recognize the norm-creating capacity of the High Court, and that doctrine's insistence on the court's purely interpretive function, ${ }^{33}$ find some justification both in the Marxist theory of norm-creation and in the High Court's place in the de facto chain of command. If the court, in a technical sense, creates norms, it does so only on sufferance.

\section{Recruiting and Tenure of the Judiciary}

This hierarchy of courts operates with a corps of judicial officers which has been almost completely changed since $1945 .^{34}$ Virtually all judges and prosecutors in office at the end of the Second World War were displaced at an early late by new personnel. The barring of Nazis and related categories from office accounted for eighty per cent of the incumbents. Of those who remained, many were presumed to have steered clear of the Nazi party mainly because of its plebeian complexion. This group did not entirely satisfy the new rulers. Furthermore, the Communists sought a radical change in social structure and property relations; to have inexperienced personnel handle the administration of justice in this situation was not as risky and costly as it might have been if superficial political change alone had been intended.

The new dispensers of justice-called "People's judges" and "People's attorneys"-first took office in the summer of 1945. At first, mandatory qualifications were simply graduation from primary school and recommendation by the local political group enjoying the confidence of the occupation authorities. Somewhat later, the completion of a four-to-six-month training course became a further requirement. By April 1953, ninety-one per cent of all judges and over ninety-eight per cent of all prosecutors were of the new, People's variety. Eightyfive per cent of the judges and ninety-eight per cent of the prosecutors were members of the Communists' Sozialistische Einheitspartei Deutschlands (SED). The old legal profession was out except for some Weimar survivors and Nazi persecutees devoted to the SED, and a handful of undaunted and adaptable careerists. Eventually, the term of the lawyers' cram courses was extended to

10 N.J. 715, 716 (1956). Directives 2 and 3 have been superseded by $\$ \$ 30-31$ of the

Penal Law Amendment Act of Dec. 11, 1957, [1957] G.B.D.D.R. 646.

33. See, c.g., Deutsches Institut Fuer Rechtswissenschaft, Lefrauch des Strafrechts der Deutschen Denokratischen Republik-Allgeneiner Teil 242 (1957). Section 9 of the new statute of the Supreme Court of the Soviet Union of Feb. 12, 1957 , indicates a differentiation between directive rulings on general questions raised by the application of legislation, constituting a legitimate function of the Supreme Court, and suggestions for legislative interpretations or changes to be forwarded by the plenary session of the court to legislative authorities. The difference, however, seems to rest more on an attempt to safeguard the prevailing Eastern theory of the sources of legal rules than on discernible differences in fact situations; for a discussion see Gsovski, Reform of the $S_{t l-}$ preme Court of the Soviet Union, 5 Highlights of CuRrent Legislation and ACtivities IN MID-Eunope 507 (1957).

34. For the initiation of the new judiciary, with local variations as remembered by participants, see Aus der Ersten Zeit Utwerer Justiz, 9 N.J. 267 (1955). 
approximate traditional university training in duration. The curriculum centered around political indoctrination. "On-the-job training" was conducted in courts and prosecutors' offices which, in turn, underwent far-reaching structural change. Zeal in pursuing the Government's objectives ranked much higher than familiarity with obsolete legal doctrine or technical skill in settling legal claims. The old law itself withered, although in most fields it was not formally abrogated..$^{3 r}$

By 1960, all members of the judiciary who do not have an academic background must pass a qualifying examination; they will be assisted by three-to-fiveyear correspondence courses with the Walter Ulbricht German Academy for Political and Legal Sciences, the fountainhead of official wisdom. ${ }^{36}$ In 1955 , the first crop of the Academy's full-fledged graduates took their places next to the original "People's judges" and "People's prosecutors." After a high-school education at the hands of "worker and peasant faculties," these students had been educated at the Academy during a two-year full-time progran. Judicial qualifications are also provided by completely revamped university law schools in a four-year curriculum. The majority of aspirants for a judicial or state attorney career are still being routed toward the universities. Recruits for the more important administrative jobs pursue their studies at the Ulbricht Academy.

Hitherto, the Ministry of Justice has appointed lower-court judges for threeyear terms, while the judges of the High Court have been elected for five-year terms by the People's Assembly. According to recent SED decisions, this system of election by assembly will, in the future, be extended to the lower courts, whose members will be elected by the district assemblies and, in the more distant future, by the people. This extension will not bring any material changes in actual selection practices. The Ministry of Justice will still exercise control, although the middle ranks of the SED hierarchy might be more closely and continually associated with the selection of the judicial "cadres."

Any judge may be removed by the appointing agency on account of a criminal record, for "violation of the constitution and other laws" and-an elastic concept - "for manifest violation of [his] duty as [judge]."37 Removal grounded on inefficiency or unreliability arising from policy disputes, possibly engineered by the party cell ${ }^{38}$ of the court itself, is a regular if not frequent occurrence. ${ }^{3 y}$

Uncertain tenure, use of the extraordinary appeal, and the fact that, as a last resort, a rubber-stamp legislature can dexterously remove the long-range consequences of an unsatisfactory judgment, serve to diminish the import of the

35. For a survey of developments in the field of DDR judicial administration by its principal architects, see Benjamin \& Melsheimer, Zehn Jahre demokratische Justiz in Deutschland, 9 N.J. 259 (1955).

36. From the ranks of justice prosecution, people's police, and other administrative offices, 474 members of correspondence courses passed their state examinations in the spring of 1958.12 N.J. 407 (1958).

37. G.V.G. §§ 16(1)a-b.

38. See paragraph preceding note 44 infra.

39. Recent cases of removal have been reported in 12 N.J. 369, 623 (1958). Disciplinary transfers may be considered common practice. 
judicial function. Unshakable validity over a substantial span of time is what lifts the legal judgment out of the stream of administrative orders changing rapidly under the impact of new impulses or an appraisal of political conditions. Such validity is not a characteristic of a judgment arrived at under the East German system. But, one might argue, an East German judge, following the provisions of the DDR Constitution, ${ }^{40}$ is still free to decide individual cases according to pre-established rules and on the basis of evidence submitted to his court. His decisions may not be upset unless certain fixed procedures are observed. Thus he is unlike other officials, who may see their decisions unceremoniously discarded or ignored by their respective hierarchical superiors. This line of argument cannot be accepted.

\section{The Informal Structure of Authority}

The legal system of the DDR knows a number of informal devices which exert enormous influence on the final effect of a judicial decision. In East Germany's legal universe, private commentaries are as rare as privately sponsored law journals. A monopoly of legal interpretation rests with the official legal authorities. If a judge finds himself in need of elucidation on a point of law which the reports or the official textbook do not provide, he may turn to the equally official law journal. But this law journal is as much an educational as an interpretative enterprise. Although controversy may be artificially stirred up for didactic purposes, the journal is primarily concerned with the "correct" indoctrination of court and prosecution personnel and carries only such articles and reports on judicial decisions as fit the purpose. Real controversy does arise if the most recent party directives and resolutions are susceptible of a variety of interpretations. But, once the authoritative gloss on the interpretation is provided, and possibly calculated ambiguities are clarified, everybody falls in line.

The absence of private commentaries is not accidental. ${ }^{41}$ Nor is it due to a "phonograph" theory of law of the kind that inspired the great legal enactments

40. Art. 127 of the constitution, reiterated in G.V.G. $\$ 5$, reads as follows: "the judges are independent in their judicial function and only subject to the constitution and the laws." However, the provision should be read in the context of G.V.G. \$ 11(1), which not only ties the judicial office holder to the observation of the constitution but demands from him that he "unreservedly stand for the goals of the DDR." The job of the East German "funcionary of justice," as he is officially and correctly called, has recently been described "as organizer of masses in the societal process of law formation and realization" rather than "as arbiter between contending parties." Strohbach, Sorgfaeltiges Studium der Partcibeschluesse verhindert Dogmatismus und Formalismus, 12 N.J. 689, 693 (1958).

41. A few years ago the official law journal permitted a judge to ask why the DDR published no law commentaries by outstanding jurists. Volkland, Ueber das Verhaeltnis zinschen Rechtwissenschaft und Justizpraxis, \& N.J. 221, 229 (1954). The answer was supplied by the highest-ranking official of the Ministry of Justice; recommending to the readers an edition of legislative texts, he disposed of the subject by saying that "brief" commentaries were notoriously "insufficient and worthless." Toeplitz, Znm Erscheinen der ncu'n Tcrtausgabch, \& N.J. 292, 293 (1954). The circumlocution made it abundantly clear that the very subject of comprehensive commentaries was tabu; the same phenomenon in Soviet Russia is described in David \& HazARd, 1 Le Droit SovIetroue 220 (1954). 
of the era of enlightenment, such as Prussia's Allgemeines Landrecht or the codes of the French Revolution. DDR doctrine certainly does not regard law as a closed system wherein the judge has nothing to do but draw logical conclusions from rigidly fixed premises. The ban on private interpretation is deliberate and political ; it serves to prevent the emergence of a rival center of legal doctrine which uncontrollable minds could use to disseminate independent opinion. Nothing could come of such independence of juridical thought but the obstruction of the Government's effort to train the judge to make unquestioning: application of the frequently changing norm to the case on the docket.

Yet not even the DDR, despite its stress on the judge's continuing "education," despite exhortations and cajolery, can force him to absorb all of the official wisdom it is so eager to purvey. So, where the call to study fails, more accentuated pressure appears. Under any legal system, cases arise that, when scrutinized by higher courts, reveal delays below and insufficient attention to one or more phases in the proceedings ; nevertheless, appellate courts often are unwilling to conclude that these factors constitute reversible error. While upholding a decision, a higher court may mention such shortcomings in passing. As the judgment on appeal-especially under the East German system, which only knows per curiam opinions-will, of necessity, concentrate on the reasons for upholding the lower court's decision, it will touch only slightly on more prohlematic points. Consequently, the lower-court ordinarily need not be unduly exercised over the appellate opinion, even though it may be critical in part. The institutionalization of judicial criticism, as introduced in paragraph four of the East German Code of Criminal Procedure, is designed to fill this gap. Whenever a case comes up on appeal, perhaps to as low a tribunal as a district court, the appellate bench may take action even when no sufficient ground to modify or set aside the judgment of the lower court exists. For example, in the event of delays in arraigning prisoners, undue adjournments or procedural mistales of one kind or another, the appellate court may expose shortconings at the lower level by publishing a piece of educational criticism. This criticism does not affect the validity of the judgment. But, reprinted in the official law journal, it is supposed to induce the court in question and other courts facing similar proilem: to discontinue the condemned practices. It is also within the authority of the higher courts to keep score on lower-level colleagues in a kind of index: file which records typical mistakes—both political and legal-and serves as a vark. mecum for selí-improvement. ${ }^{42}$

Both institutionalized criticism and an occasional index file of typical mistakes focus only upon the segment of cases which come to the higher court's knowledge by way of ordinary or extraordinary appeals or protests. In actual practice. only a fraction of lower-court cases attract the attention of the courts above. Review of the lower-court proceedings at the request of the prosecutor general

42. See the proclamation of the Leipzig Administration of Justice, reprinted in 7 N.J. 725 (1953); Grass, Trautzsch \& Stiller, Die Selbstwerpflichtungen des Becirksgerichts Leipzig zum Jahr der grossen Initiative, 7 N.J. 759 (1953). 
or by order of the High Court president takes place, as a rule, only when this or that segment of the SED especially interested in upsetting a specific judgment exerts sufficient pressure. ${ }^{43}$

Seen from the authorities' viewpoint, these institutionalized checks-appeals, extraordinary appeals, judicial criticism, helped along by some measure of law periodical comments-have one essential shortcoming. They leave open to what extent and with what dispatch the lower courts will be able to produce decisions in conformity with announced official policies. Consequently, a network of political and moral pressures influencing and determining the attitudes of the judiciary has been built up to complement both the educational processes and the institutionalized checks on the judges' individual decisions. The call to self-improvement is the central theme of these additional controls.

Self-improvement does not come automatically. A double-pronged machinery sets it in motion: on the upper level, the Ministry of Justice and, for the prosecutors, the Attorney General's office; on the lower level, the individual court's party unit. This unit comprises all party members from the presiding judge to the charwonian. Often, the court's administrative officers, who make the assignments and supervise the docket, enjoy a higher party rank and corresponding influence on the cell's resolutions than does the judicial personnel. It is before this body that the judge, as any other party worker, undergoes the ritual of "self-conmitment." The "self-commitment" pledge specifies areas of mandatory improvement, either along the lines of previous criticism by superiors or party officials, or else simply in dutiful observance of recent policy pronouncements. In addition, each court holds frequent judicial conferences. Every judge is expected to submit a progress report; the individual members' weak spots are discussed, and the more advanced ones straighten out those who fail. When necessary, the party "plant unit" deals with obstinately repeated "mistakes."

How effective is self-improvement guidance by higher courts and party pressure? Much though it may upset the Government, the answer always depends on the individual judge's zeal and application-another uncertain factor. Strong emplasis is therefore placed on continuing supervision by "instructors" who are expected to give the everyday activity of the judiciary a steadier direction than could emanate from the higher courts. In the person of the instructor, the joh of functional and political supervision merge; he studies, compares, evaluates and criticizes the judge's performance from both professional and political viewpoints. Instructors operating out of the Ministry of Justice and the Office of the Attorney General reach down to the level of district courts and district prosecutors; in turn, instructors at the district level are assigned to the local courts. In addition, a whole brigade of inspectors, namely all the district instructors, some district court judges, and personnel officers accompanied by the executive officer of the local court under review, administer an annual

43. In a reply to critics, such operational breaks were cited by High Court Deputy President Walter Ziegler as a chief reason for the highest tribunal's shortcomings in the implementation of governmental policy. Ziegler, supra note 32, at 717 . 
evaluation of each court's performance. ${ }^{44}$ The court's executive officer is then of particular value, both on account of his familiarity with the judges' records, as well as for his standing in the party organization, which casts him in the role of the court's permanent political supervisor. ${ }^{45}$

One story tells of an over-eager chief instructor who, feeling misgivings about a specific decision, went out to interview local people. When he had assembled the facts, he discovered that the court indeed had been at fault and the reasons for the error. ${ }^{46}$ Was this his real mission? Not according to prevailing opinion in the mid-1950's. Most comments have expressed the view that it is not the instructor's function to retry individual cases. The emphasis is on improving the quality of the court's work rather than on securing justice in particular instances. Cultural and political problems are to be investigated. Judges are to be counselled as to the political and social imperatives and why judgments based on proper fact finding and sound legal reasoning may be utterly wrong when the social and political implications of both the incriminating act and the judicial decision are left unheeded. Within this framework, judicial opinions are thoroughly studied. The performance of the individual judge and the political effect of his overall judicial record are evaluated by instructors and discussed with him. Beyond this, the annual inspection is to ascertain the extent to which each court's collective effort contributed to the fulfillment of the judiciary's political and ideological obligations. As the political situation changes, however, so may that of the inspection brigade. The greater the pressure on functionaries of the judicial apparatus for active political participation, the more pronounced is the inspectors' tendency to reinvestigate cases, to expose their class contents and the roles of the parties and the judge's "formalistic" neglect of these factors. ${ }^{47}$

Among the various techniques devised to make the judge concentrate on doing a political job for the Government, the combination of everyday supervision and counselling by instructors and annual roundups stands out. This combination is pervasive and has become symbolic of the courts' role and position. Whether a judge is good or bad is measured on a scale which registers his ability to grasp and assimilate, at any given moment and without delay, the government view

44. Inspection reports are frequently discussed and suggestions for improvement offered in print. See Boehme \& Krueger, Die Arbeit der Instrukteurbrigaden bei Rovisionen verbessern, 10 N.J. 11 (1956); Ostmann, Ueber die Justizveri'altung, \& N.J. 37 (1954); Streit, Aus den Erfahrungen einer Brigade im Beairk Potsdam, 12 N.J. 620 (1958); Windisch, Die Veraenderung der Instrukteurtaetigkeit in der Staatsanwaltschaft, 12 N.J. 839 (1958).

45. Separate inspection teams within one jurisdiction, assigned to the court, the prosecutor's office, and the police department, actually proceed with a degree of coordination-though not necessarily in complete agreement with one another-so as to bring into the open interdepartmental friction and rivalry and obtain uniform corrective results. Cf. Gerhardt, Ueber die Durchfuehrung von Revisionen, 10 N.J. 600 (1956).

46. Becker, Eine praktische Methode der Revision, 10 N.J. 359 (1956).

47. See the recital of the experiences of the inspection brigade in the Potsdam district in Streit, Aus den Erfahrungen einer Brigade in Bezirk Potsdan, 12 N.J. 620, 621 (1958). 
of the political and social situation. "First and foremost in the instructor's work," as one of the architects of the system put it, "is immediate transmission from the top to the bottom; ... . he is a helper and political advisor." 48

But however faithful and eager the transmitting agents may be, the Government's political vista is bound to suffer in transmission. Even agents who knew all the answers and could correct all conceivable mistakes would not be able to eliminate or prevent error, deviation, and lack of intuitive political adaptability. The true test of their achievement is in the frequency and intensity of the judges' voluntary, spontaneous identification with the DDR's political leadership. Ideally, the judicial act would be transformed into an abstraction unrelated to social reality. All societal differentiations would become submerged in universal identity, wherein the mind of the judge unconsciously but unremittingly communicates with the all-pervasive mind of the Governmenttotalitarian reality taking the form of ultrademocratic chimera.

\section{The Judge and the Other Organs of the State}

It is doubtful whether in German trial practice an equilibrium ever existed between the defense lawyer and the prosecution. Somehow, in spite of his theoretical status as officer of the court, private counsel could never quite compete with the prestige of the prosecutor, representative of the most "objective office" of the world, as it was known in official parlance. But, whatever the previously existing element of imbalance, it has increased many times over in the practice of the DDR. The lawyer has lost in status as a professional man and consequently in usefulness to his client. This is as much due to the fact that the DDR is too busy reforming the life habits of its members to care much about equipping them with efficient means to defend their claims as to special measures aimed at narrowing the prerogatives of the profession. The Code of Criminal Procedure is not overly concerned with the lawyer's prerogative. But it is the disregard for the Code by prosecutor and judge and ${ }^{49}$-as important-the reevaluation of the respective position of defense and state authority, to which the system constantly draws the lawyer's attention, that has limited his field of activity. Moreover, since 1953 the lawyer has increasingly been unable to exist as an independent professional entity conducting his business either alone or in free association. New lawyers can be admitted to practice only as members of the official lawyers' cooperative. Disabilities for nonmembers and privileges for the joiner make continued independent practicing a hazardous affair ;

48. Benjamin, Der Instructeur-Helfer und politischer Berater, 8 N.J. 285, 290 (1954). For more recent discussion see Bildermann, Einige Hinweise fuer die Revision der Kreisgerichtc, 11 N.J. 272 (1957).

49. During the short-lived thaw of 1956, the President of the Berlin Lawyers' Cooperative drew up a kind of list of grievances. See the report on the meeting of the chairmen of lawyers' cooperatives, Iragen des Strafrerfahrens c'om Standpunkt des Verteidigers, 10 N.J. 434 (1956).

50. The decree on the formation of lawyers' cooperatives dates from May 15, 1953. [1953] 1 G.B.D.D.R. 725. The "model statute" attached to the decree has been consider- 
the net effect is to undermine the fundamental relationship of trust between lawyer and client. In turn, the cooperative's administration-which assigns cases and clients-has recently been the object of special attention and "ideological schooling" on the part of the Ministry of Justice. ${ }^{51}$ Whether the deprofessionalizing influence of this new bureaucratic fetter is balanced by the radical elimination of the lawyer's predominantly pecuniary motivation, on which official criticism of the capitalist lawyer lays such stress, is an interesting if debatable point. ${ }^{52}$ At any rate, as the prestige of the profession is incommensurably lower than that for other law jobs, and as the style and condition of the new society allow for only limited use of the lawyers' intellectual equipment, its members scarcely do now, nor can they in the future, form any counterweight against the prosecutor in his present role.

Inasmuch as the Attorney General's and Minister of Justice's activities are coordinated by the incumbents' common zeal to transform into administrative practice the impulses and orders received from the highest party authorities and formalized by the Council of Ministers, the independent position of the Attorney General's office may be of more symbolic than actual importance in the DDR scheme of things. Nevertheless, its enhanced status has some impact on the style and method of DDR policy. Through its determination of the competent criminal court and its power over extraordinary appeals, the Attorney General's office plays a primordial role in blocking out penal policy.

The political importance of the case rather than the fine art of legal classification determines the conduct of the prosecution. Political guidance may take a variety of forms. The first job of the prosecution is to spot the possible political implication of a given situation. The more tightly the Government controls opinion-molding, the more visibly will political coloring tinge every seemingly private situation. Divorce, libel, assault, the mistreatment of animals -all might acquire a political meaning. ${ }^{53}$ Slight stirrings of misgivings, douhts.

ably changed through the introduction of tight official supervision of the conperatives' activities by Decree of March 22, 1958, [1958] G.B.D.D.R. 311.

51. A list of grievances against the lawyers' cooperatives' lack of social consciousness together with recital of officially applied remedies has recently been furnished by the ministry's specialist in charge of lawyers' affairs. Helm, Fragen der Entziscklnng einer sosialistischen Rechtsanwaltschaft, 12 N.J. 298 (1958). Mixed control brigades with the participation of the Ministry of Justice, the SED and the Association of Democratic Jurists are now recommended for supplementing the feeble activities of the lawyers' cooperatives' own control commissions and as a means of bringing the cooperatives up to required standards. See the official report reprinted in 12 N.J. 665 (1958).

52. Lawyers' cooperatives still try to keep membership down in order to maximize members' incomes, see Helm, stipra note 51 , at 300 , but this may be part and parcel of the "unsatisfactory political and ideological condition" of the cooperative.

53. The interaction between public opinion, the various echelons of the party bureaucracy and the corresponding legal authorities is illustrated in the curious story of an all-tooconscientious SED factory guard. He was tripped up by the irate staff of his plant when he was caught maltreating and cruelly killing a vagrant dog which somehow had gotten on the plant property. Ejected under public pressure from both his job and the party, he 
passive resistance or more active insubordination may pass through devious channels before they appear in the trial setting as private quarrels or trifling brushes with the lower fringes of authority. The very frequence of such cases betrays crammed living in a climate where complaining and personal grudges take the place of self-expression and personal endeavor. In the eyes of the rulers, even the least significant and most ludicrous or banal run-in necessarily assumes a more sinister complexion. In every aimless individual reaction, the exponents of governmental power are bound to look for traces of a repetitive, rebellious design.

Such are the situations with which judge and prosecutor, without special signals from higher authorities, must deal, day in, day out, in the required political manner. They are on their own, at least at the trial stage; in a way, the individual setting is unpatterned in the development of the plot attentively watched by participants and bystanders. Without genuine newspaper coverage, repercussions of scenes on the judicial stage are weak. The most limited effect remains hidden from the actors for the identical reason. It is the educational job of the office of the Attorney General to train even the lowest local staff member to recognize incipient political situations and their implications on his own.

If a case has been referred to the Attorney General's office by political authority, if it has the making of a cause célebre or at least suggests that it could be widely used for propaganda purposes, the prosecutor may be under orders to tell the court unequivocally how he would like the case to be handled with regard both to penalty and applicable law. Thus, the expected roles are reversed. In theory, under the DDR code no less than under most continental codes, it is up to the court to choose the legal formula to be applied in a given criminal situation. Deprived of this interpretive function, the court is hamstrung in its punitive role as well. With respect to the punishment to be imposed, the court, under a widely accepted doctrine, may disregard the authority of the Govern-

was also sentenced by the local court to one year in prison and a fine. When the defendant managed to get the ear of the higher authorities, the story took a different complexion. The personnel chief of the plant was removed from both the plant and the party roster and the local party secretary was severely taken to task for having lost the ability to recognia the enemies of the working class. A week before the discussion of the incident at the SF.D's fourth party congress, the High Court - on an extraordinary appeal by the Attorney Teneral-quashed lower court proceedings and acquitted the defendant as having acted within the purview of his duties. The judgment sharply castigated the local prosecutor and both the local and the district court judges, who on appeal had only rescinded the privon sentence without otherwise modifying the conviction, for having allowed themselves to become bamboozled by the class enemy. High Court Judgment of March 29, 1954, 8 N.J.

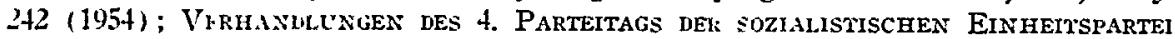
1)vutsinganis 30. MARz BIS 6. ApRl 1954, at 180 (1954) (Ulbricht) ; $i d$. at 559-60 (discussion speaker Iiefer). The story of the "dog of Muehlhausen" has entered the legal hagiography of Eastern Germany as the fourth party congress's legacy to the legal fraternity, the living example of the dialectical unity of legality and "Parteilichkeit." See Benjamin, Vom IV. zum 1 . Parteitag der sozialistischen Einheitspartei Deutschlands, 12 N.J. 437 (1958). 
ment, as represented by the prosecutor, only if it holds a basically divergent view. ${ }^{54}$

Of course, the burden of the judge in a case tried under Klieg-light conditions might be eased by his administrative superiors. The official intervention of the prosecution's representative might go hand in hand with direct-though behind the stage-intervention from the higher echelons of the Ministry of Justice. In these instances, ranking officials of the Ministry would confer with the judge about the disposition of the case. This, however, is mostly limited to exceptional situations justifying spectacular legal or propaganda performances. Frequent repetition would expose too many fissures; show trials as an everyday affair might generate indifference and cynicism instead of that tremor which electrifies the faithful and makes the timid pledge active allegiance. The requisite minute preparation of the show to be staged and the public reaction to be evoked pays off only in cases of outstanding political importance. But, while individualized high-level production design and stage direction are infrequent, the political approach to justice is never absent.

It is for this reason that the prosecutor, who embodies the permanent state interest and who, at least in theory, is fully cognizant of the actual needs of the political powers ${ }^{55}$ at each and any moment, has a far stronger impact at the trial stage than that of a mere counterbalance against the defense, as he was conceived in old-style continental doctrine (now deemed rather unrealistic -not without obvious justification-by East German penal practitioners). True, at the pretrial stage, a preventive detention warrant must be signed by a judge. But here the judge's power ends; at least on paper, the prosecutor is in charge of everything else..$^{56}$

In everyday practice, the stature of the prosecutor's office, tremendously enhanced vis-à-vis defense and court alike, does not appear quite so big. The criminal procedure code's "investigative organs," the criminal police and the ubiquitous security services, tend to relegate the prosecutor to the role of manager or writ-signer. This much was officially admitted during the brief

54. Attorney General Melsheimer, Sozialistische Gesetzlichkeit im Strafverfahren, 10 N.J. 289, 295 (1956).

55. The gap between theory and practice, however, is considerable, and the "revision reports" are full of complaints about wrong political estimates and lack of politicalideological clarity and of unified political line in the district and county prosecutors' offices. For a recent criticism on the basis of experience in the Magdeburg district, see Spranger \& Wunsch, Ueberwindung von Maengeln in der Arbeit der Justizorgane und der Staatsantwaltschaft in Besirk Magdeburg, 12 N.J. 267 (1958).

56. Judicial pretrial investigation has been abolished, leaving pretrial proceedings concentrated in the hands of the prosecution or the "investigative organs." If necessary, the prosecutor orders search and seizure. See C.C.P. $\$ 116$. The "investigative organs" may do likewise, with the judge relegated to confirmation within forty-eight hours. See C.C.P. $\$ 140$. During the trial, the prosecutor may put direct questions to the defendant, while the latter's lawyer may question only through the presiding officer of the court. C.C.P. $\$ 201(2)-(3)$. The prosecutor sets conditions on lawyers' visits with defendants during pretrial investigation. See C.C.P. $\$ 80.3$. 
political thaw of 1956 when the prosecuting staff's position as second fiddle to the security police was deplored and remedial action suggested.

Notwithstanding the extended role of the police, the prosecution's power remains spectacular, especially since the DDR, following the Soviet example, has made the prosecutor's office the kingpin of what might be called an attempt to establish an intrabureaucratic balance. Because the Communist regime's parliamentary bodies lack popular backing and because the interests of their members too closely intertwine with those of the executive to allow them to play the role of their brethren's keepers, those bodies cannot fulfill the job of watchdog and critic of the administration. Thus, in order to avoid entrusting control completely to hierarchical superiors, departmental duties must be parcelled out in such a way as to make one department supervise and criticize the activity of another. The premise is that, within one departmental branch, the higher echelons are too much involved in the quality and detail of that department's performance to be honestly and impartially critical. Consequently, criticism should be the function of an outside agency. This sums up at least part of the reasoning which made the DDR follow the Russian model in assigning to the prosecutor's office the task of watching over the legality of administrative performance across the entire range of governmental services. ${ }^{57}$

The flaw in this kind of reasoning is obvious. No matter how painstakingly the prosecutor's men may wade through collections of laws and ordinances, make their inspection trips and investigate individual citizens' complaints, they will always be on the outside. ${ }^{58}$ Unfamiliar with the day-by-day techniques and shortcuts of the agencies under review, the best they can do is detect manifest violations of the law. The prosecutor's office then may enter a protest and, if it carries enough weight at the moment, compel change. But the change

\section{S.A.S. \$\$ 10-15.}

58. In 1957 the purely bureaucratic character of the prosecutor's function as general watchdog of legality was established by the then Deputy Attorney General. Haid, Einige Aktuelle Probleme der Staatsanwaltschaftlichen Arbeit, 11 N.J. 796 (1957). His job was defined as one of following up complaint signals, but not as undertaking investigations on his own. But meanwhile this ranking official had been found "to have knuckled under to the attacks of the imperialists and (in conjunction with the Wollweber group) to have taken a revisionist position." Neues Deutschland, June 13, 1958, p. 4. See also Bohm, Verbesserming der Arbeit der obersten Staatsanwaltschaft, 12 N.J. 629, 630 (1958). By summer 1958, we therefore find the members of district attorneys' offices developing the "new style of work" prescribed by the fifth SED party congress. It may-even go so far as to include putting in a two-week stint with agricultural cooperatives (present day "points of concentration," see note 97. infra), in order to be always at hand when advice and support is needed. But in spite of this feverish activism it seems doubtful whether control includes systematic, around-the-clock and self-initiated inspection of legality. Even the introductory text accompanying the Attorney General's new directives of July 23, 1958, starts with the admission that the prosecutor has a hard enough time to take care of his in-box. Attorney General Melsheimer, therefore, sticks to the ritual of recommending close cooperation with other power holders and of prescribing the special initiatives needed for taking care of present "points of concentration." Melsheimer, Die Aufgaben der Staatsanz'altschaft nach dem V. Parteitag, 12 N.J. 511 (1958). 
will not eradicate the evil rooted in a chain of command over which the prosecutor's office has no jurisdiction.

In the mutual supervision schemes conceived to maintain intrabureaucratic equilibrium, local and district courts are on both the giving and receiving ends. The institution of judicial criticism enables them, if pertinent facts should come to their attention, to expose administrative activity inconsonant with the law. So far, they have not made extensive use of this privilege-out of laziness, some critics assert. ${ }^{59}$ The courts themselves are obligated to report regularly to the local and district municipal bodies' committees on administrative and police affairs. In addition, since 1957, an obligatory annual report is submitted to the local deliberative assemblies, whose critical objections must be answered within four weeks.

Such intrabureaucratic criticism is no substitute for public reaction, but under certain circumstances it may provoke, channel or, more often, simulate genuine public response. There is no way to predict whether local power positions will suffer from being pitted against each other or whether they will merge into consolidated power blocs, all local machines uniting to form a single mutualaid society. Preservation of the intrabureaucratic balance must never be taken for granted, even though hierarchic dependencies, performance reports, and deadlines are designed to ensure it in a mechanical way.

\section{The Judge and the Community}

In so far as the working of intrabureaucratic controls is at best a haphazard affair, they must be supplemented by drawing the people at large into a role which the official institutions perform unsatisfactorily: that of the friendly critic who voluntarily and actively participates in the development of the country's institutions. But the attainment of this goal depends upon whether the judge succeeds in winning the trust of the population. Developing proficiency in performing just such a feat has been one of the regime's permanent and urgent concerns.

How is the judge to prove worthy of trust? As he no longer freely arbitrates when the individual clashes with the Government, what does his superior knowledge of established norms or his keen insight into the hardships and conflicts of daily living matter to the public? In fact, the judge can win acclaim only if he has a chance to apply a good law or help enforce a government program that makes sense to people. Apparently, Soviet jurists and their colleagues within the Soviet orbit recognize this problem; when the party, in the wake of the Twentieth Congress of the Communist Party of the Soviet Union, denounced them for inhuman, bureaucratic and formalistic handling of the law, they retaliated in kind and publicly urged that the people be given good statutes, carefully drafted and easy to understand.

But then, what laws are "good" in the judgment of the people? Many norms

59. Streit, Einige Hinweise zur Auswertung der 3. Parteikonferens der SED, 10 N.J. 257, 258 (1956) ; Berg, Zur Anwendung der Gerichtskritik, 10 N.J. 307 (1956). 
the judges must observe exist in the area of purely technical regulations or fields unrelated to the actual distribution of power; they do not represent contentious issues to the average citizen. In other spheres-for example, violence against persons-the system that most unobtrusively ensures peace and quiet in interpersonal relations and prevents turbulent flare-ups will meet with the widest approval.

In a more controversial area-divorce-neither legislation nor the judiciary has been able to establish clear-cut normative standards. The search for guilt has been eliminated by legislative fiat. ${ }^{60}$ The courts now oscillate between, on the one hand, required societal standards-the welfare of the children and the stability of interpersonal relations as a prerequisite of labor stability-and, on the other, the objective degree of a couple's alienation. Yet, especially in lower courts, something alsin to guilt enters, so to say, through a legitimate sidedoor. Courts invoke the legislatively sanctioned consideration of "intolerable hardship" for the respondent when refusing a divorce. While the perplexity of the courts before this problem is evident, they should, in the public's mind, softpedal the cynical emphasis on the State's interest evident in earlier decisions. And the courts have learned that, at least in this context, state interest is ambiguous and far from easy to determine in the individual case. The public undoubtedly will give them credit for a measure of honest and realistic striving to solve the riddles of what, in spite of all exhortations to the parties concerned to demonstrate higher forms of "socialist consciousness," remains an essentially private relationship. ${ }^{61}$

As for laws dealing with the protection of the economic order, popular response is probably ambivalent. Offenses in this sphere may give oppressed citizens the same feeling of satisfaction which they derive from any act flouting the public order, especially a violation with political overtones. But tacit emotional complicity may be replaced by hostility when the offense has caused inconvenience or material damage to known groups of citizens. Perhaps judicial sanctions will not then be questioned; they may even evoke applause. A psychoanalyst, arguing from transference theory, might suggest that such behavior would provide a vicarious outlet for aggressive feeling that otherwise would converge upon the prevailing authorities.

In any event, the Government is always eager to use the judge's contacts with the citizenry to gain greater resonance. The men of the judiciary are saddled with heavy chores foreign to the judicial function as conceived by the Western mind. Judges are called upon to take part in variegated election

60. Marriage Decree of Nov. 24, 1955, [1955] G.B.D.D.R. 849, \& \&.

61. The High Court Directives No. 9 and 10 of July 1, 1957, 11 N.J. $441-49$ (1957), the first discussing the substantive problem of divorce, the second the procedural aspects of divorce and alimony, testify to the dilemma discussed above. Standards of "objective alienation" seem to vary. They are more severe when children are still to be taken care of than where only the mutual relations of the partners are concerned. At any rate, in the latter case the by no means unambiguous terms of the directive strive towards limiting the invocation of "intolerable hardship" as grounds for refusing a divorce. 
campaigns; sometimes this adds-in an ambiguous way--to their political prestige. As part of the regular routine, they attend and address plant meetings, conventions of farm cooperatives and other officially sponsored gatherings $;^{62}$ there, they may either vaingloriously orate on general suljjects or, talking about their workaday business, try to obtain a sympathetic hearing for the courts' problems and difficulties.

Many a campaign to bring the judiciary and the population closer together has been tested. For example, two have been launched, after careful preparation and a great deal of publicity, to mobilize public interest and cooperation in the election of lay judges. ${ }^{63}$ Considerable effort has been exerted to make the individual citizen pay attention to and assume responsibility for the work of the courts. Special courses are set up to train lay assessors; those elected are organized in "collectives" and required to report to the plants and offices from which they were elected. In some places lay assessors attend, over and above their trial duties, court sessions focused on criticism of past judicial performance.

Shunned by the average citizen, the lay assessor's part-time office at first attracted the wrong people. Many elected assessors had to be eliminated as unfit. By stressing the educational aspects of judicial work, the Government expects to obtain more willing participation on a wider range. The expectation may not be altogether baseless, since people in the DDR can hardly escape "honorific" public duties of one kind of another, and service as a lay judge may be tempting as a politically uncolored and uncompromising chore. $\Lambda$ s the employer of some 40,000 lay assessors, the Government perhaps should not tell a reluctant candidate: "You don't hold any office yet, Heinrich, why don't you tackle the lay assessor's job on the local court? You won't have anything to do there but nod your head once in a while so you won't fall asleep." ${ }^{4}$ But the formula works with some success.

The duty of protecting adherents and functionaries of the regime against outbreaks of popular hostility keeps the judge from entering very far into the people's confidence. To an average citizen, the declared enemy of the regime,

62. In quantitative terms the turnout looks impressive. In 1957 courts conducted 11,280 popular meetings on administration of justice problems. These meetings were attended by 530,000 visitors. But the prosecutors did even better. Their 15,130 meetings drew 830,000 visitors. To these figures 11,000 "judicial accounts" before popular meetings and 14,000 meetings preparing the election of lay assessors must be added. These statistics are given by Benjamin, Die dialektische Einheit von Gesetslichkeit und Parteilichkcit durchsetzen!, 12 N.J. 365 (1958).

63. Trial by jury was virtually abolished in Germany as early as 1923. Instead lay assessors, selected from panels drawn by municipal bodies, were made voting tribunal members. After the collapse of Nazi rule, this Weimar setup was fully restored in East and West. The main innovation subsequently introduced in the DDR was election of lay assessors at places of employment, i.e., industrial plants, offices, collective farms, etc.

64. This suggestion is drawn from comments by a law assessor in Die gegenwärtigen Aufgaben der Schöffen. Zentrale Schöffenkonferenz am 3. und 4. November 1956, at 43 (published by the DDR Ministry of Justice, Berlin, 1956). 
the spy, or the deviator within high party ranks remains a figure from another world. But the local hero of labor, the rural party potentate or the meticulous police officer are familiar to everybody. During a drunken brawl, many a pent-up hatred may take the form of an insult or, if inebriety progresses further, an assault against these worthies. With an assist from local witnesses, the county court judge, given a chance, might try to reduce such rather frequent occurrences to their lowest legal denominator. ${ }^{65}$ But the party functionary, the higher court judges, the instructor from the Ministry of Justice will be on the watch to ensure that these insults and affrays are not downgraded to harmless disturbances of the public order, and are correctly treated and punished as major threats against the security of the country. ${ }^{66}$ The judge's friendly contact with the community must never advance to the point where he loses his complete identification with the powers that be.

The same need to protect loyal adherents of the regime lies at the bottom of the new-fangled concept, "socially justified criticism." What is at stake under this rubric is not so much the judge's popularity with the community at large as the law court's duty to protect third-party interests. "Socially justified criticism" accords judicial protection to the criticism of individuals by other individuals, a process popularly called "denunciation" and rooted in the spontaneity of petty interest, envy, rivalry and personal animosity. Carry a tale about $X$ to the personnel director of the plant or make a derogatory comment about $Y$ in every neighbor's hearing in the village square, and the DDR High Court will commend you for "socially justified criticism" so long as $X$ 's or $Y$ 's actions or their possible consequences may be construed as harmful to society. This atmosphere permits a woman party member in good standing who holds a grudge against a female neighbor to go to the personnel office of the plant where she works and mention male visitors entering or leaving the neighbor's apartment (even when the neighbor was not at home). Her "criticism" will be "socially justified" provided she does not forget at the start to mention a brief case of papers that the suspect neighbor brings home every night. ${ }^{07}$

By the courtesy of the high tribunal, a new evidentiary privilege has been

65. Complaints against lower judges' failure to sense the correct political implication of such insults and brawls are frequent in the official legal literature. For an example from recent months, see Spranger \& Wunsch, supra note 55, at 270; Streit, Fuer einen neuen Arbcitsstil in der Justiz, 12 N.J. 368 (1958); Streit, Aus den Erfahrungen einer Brigade in Bcsirk Potsdam, 12 N.J. 620 (1958).

66. See, e.g., High Court Judgment of Feb. 11, 1958, confirming a district court judgment sentencing the drunken attacker of a "hero of labor" to eighteen months penal servitude by applying $\$ 19(3)$ of the Penal Code Amendment Act of Dec. 11, 1957, [1957] G.B.D.D.R. 645-an aggravated case of state-endangering agitation. 12 N.J. 323 (1958). For a parallel case involving party-school students, see High Court Judgment of March 21, 1958, 12 N.J. 391 (1958).

67. Lower court proceedings in Streit, Uber die Abrenzung von Kritik und Beleidigung, 10 N.J. 176 (1956) ; High Court Decision of March 2, 1956, id. at 217. For further comment, see $i d$. at 230 . 
born, one that does away with the search for truth or falsehood. ${ }^{\text {88 }}$ "Socially justified" allegations require no evidence. Further, the "critic" need not bother to adduce proof of legitimate interest, despite the fact that a defendant in a libel suit may have to supply such proof even though the formally libelous statements admittedly be truthful. No "socially" justified" informer has to hide his face in shame; he has done his duty as a patriot and the Government will insist that the community honor him for undaunted civic devotion. ${ }^{69}$

To be sure, any government may use, encourage and protect informers. But to insist that the public larish praise on them, and to hold them in so high esteem as to deny the aggrieved individual the right to legal relief from their abuses, are unusually bizarre procedures. Surely, this brazen "social justification" may swell the ranks of informers. But it also may overrrate the malleability of public sentiment. The public's verdict may continue to depend upon a popular and realistic evaluation of the "critic's" motives or of the cause he claims to serve.

Public response and civic activity are elusive and hard to come by under the DDR's unrelenting control. Even so, a shaky pedestal for the volunteer informer is a skimpy reward for the Government's continuous effort to produce such popular participation in the new rule. This failure may be a measure of the fissure between party theory and public acceptance. Yet, "socially justified" and extolled as a boon to society, the informer may at least add a more lively beat and genuine unpredictability to the prearranged motions of the intrabureaucratic pendulum.

\section{"Socialist Legality": Doctrinal Gyrations}

Since de-Stalinization was officially inaugurated at the Twentieth Congress of the Communist Party of the Soviet Union, strict observance of "socialist legality" has been the theme of many party and government pronouncements in the DDR no less than in other countries of the Soviet bloc, and the protection of individual rights has been steadfastly emphasized. ${ }^{70}$ This purportedly libertarian philosophy was part of the general reaction to the denounced "ex-

68. Refusing to test the reracity of a defendant's allegation to the effect that plaintiff had placed milk to be delivered to a dairy center in his toilet cabinet for overnight storage, the court said that it was the defendant's duty to criticize unhygienic conditions, for improved hygiene was an element of social progress. See High Court Decision of Sept. 1, 1955, 9 N.J. 634 (1955). Actual presence of unhygienic conditions obviously is immaterial; the mere possibility of the occurrence is a threat to social progress and must be denounced.

69. The underlying policy and principle has been expressly reaffirmed by a plenary High Court Decision of Feb. 21, 1958, rendered in pursuance of an extraordinary appeal of the Attorney General. 12 N.J. 289 (1958). For a comment in a similar direction, see 12 N.J. 315 (1958).

70. Both points were stressed in the Central Committee's report to the congress. Khrushchev, Otchetnyi doklad TsK KPSS XX s'yezdu partii 109 (1956). The resolution subsequently adopted by the congress insisted on the "strengthening of Soviet legality" and urged that the rights of citizens guaranteed by the soviet constitution be "rigorously respected." 
cesses" marking the close of the Stalinist era. Yet, "socialist legality" or "Soviet legality" (called "revolutionary" in earlier years) is not a recent innovation, nor is its essential meaning encapsuled in guarantees of personal security. The concept goes far beyond anti-Stalin polemics.

In the early days of Soviet power, "revolutionary legality" was governed by the practical requirements of a factual situation. Communist teaching clearly stated that the working class had taken hold of governmental power and would use it to further its own interests. Subservience of the government machine to proletarian class interest was deliberately flaunted; to quite some extent, legal "formalities" were considered unnecessary. The standard-bearers of the victorious revolution took pride in divesting power relationships of legal adornments. "Bourgeois legality" was exposed as a fraudulent maneuver to prevent the oppressed from recognizing the true balance of power. Law, then, was just another ideological mask of domination, not necessarily the most important one.

It was not for abstract philosophical reasons alone that Lenin felt irked by the emphatic concern for the principles of justice and personal freedom which his short-term non-Communist People's Commissar for Justice displayed. The maker of the revolution. who once had practiced civil and criminal law before Tsarist courts, avowedly had no patience with what to him was a matter of form without intrinsic value, even though considerations of expediency made occasional observance of the principle of legality advisible. ${ }^{71}$ When he in turn insisted on strict adherence to revolutionary legality, he meant only that all action emanating from organs of the revolutionary government must follow the pattern outlined by the central authority and must keep within the rigid confines of its directives. In essence, the concept of legality was directed against decentralization of power, uncoordinated action, and spontaneous initiative beyond that specifically authorized by the party's governing body, or by agencies to which that organ had delegated power. ${ }^{72}$

71. One writer has narrated the following episode:

We were discussing a harsh police measure with far-reaching terroristic potentialities. Lenin resented my opposition to it in the name of revolutionary justice. So I called out in exasperation, "Then why do we bother with a Commissariat of Justice? Let's call it frankly the Commissariat for Social Extermination and be done with it!" Lenin's face suddenly brightened and he replied, "Well put . . . that's exactly what it should be ... but we can't say that."

Steingerg, The Workshop of the Revolution 145 (1953).

72. By this very token, "revolutionary legality" was to bar abuse of power by individual government or party officials. In his last active period Lenin repeatedly insisted on combatting abuse of power, a task he thought it best to entrust to the prosecutors' offices with the rigid proviso that all cases of violation be referred to the courts. See Lenin, $O$ 'dvoinom' podchi nenii $i$ zakonnisti, 33 Sochineniya 326-30 (4th ed. 1922). Later, in Stalin's interpretation, things were to be simplified to the extreme. In Stalin's view, which until his death was the law of the land, the history of revolutionary legality was reduced to two major phases. In the NEP period, when private enterprise was deemed indispensable, legality was to prevent excessive levies and confiscation of private property, but after the 
In this view, legality is nothing but a technique of domination. The party alone decides whether law or another instrument of social control should be given precedence. Law serves the ruling class as a tool for modifying or shaping the development of society, and revolutionary legality stands for planned, coordinated and disciplined exercise of class rule. ${ }^{73}$

Not substantially molded by the institutional setup in which it appears, legality takes its contours from the class that imposes it. Law is oppressive, fraudulent and reactionary when in the hands of a class doomed to defeat; it is an instrument of liberation and progress when serving a class destined to chart society's future course. Judged by its result rather than the modes of action it embodies, legality is like the twin but respectable brother of terror to whom a more specific task is assigned: ensuring the regularity and predictability of behavior.

According to the Leninist interpretation of the historical process, the principle of revolutionary legality takes added validity as a guide to action from the historical function which it must perform. Seizure of the government machine by the proletarian vanguard is not just the fortuitous outcome of transitory factual elements. It is an historically necessary event which marks a specific stage in the evolution of human society. The revolutionary working class, the first class to gain scientific insight into the objective laws of social development, is given the unique chance of adapting its action to historical necessity. From the laws of history, the workers derive binding norms of conduct endowed with objective validity. Revolutionary legality sums up the set of such norms applicable after the conquest of power and enables the victorious working class to fulfill its historical mission. For those in charge of making the new system work, legality is more than any single one of many conflicting directives, more than a warning to those who may be exposed to the new government's coercive pressure. A manifestation of the objective historical process, socialist law sets an inescapable behavior pattern for a clearly defined historical period and prescribes norms of conduct hallowed by recognizable and recognized historical necessities.

Though Lenin did not elaborate the historical role of revolutionary legality, it is easily deduced from his doctrine of the proletarian revolution. An eminently pragmatic thinker, however, Lenin always took care not to detract from

completion of the "foundations of socialism" its function had become protection of public property. This Stalinist gospel was severely taken to task in the very first official comment released after the Twentieth Congress. It was authoritatively stated that Stalin's version was neither "exact" nor "comprehensive." Soviet legality was defined as (1) "a precondition of and means to organize and develop societal relations," (2) "the foundation of governmental discipline" and in addition (3) "it safeguards the rights and legitimate interests of the Soviet citizens." Strogovich (Corrresponding Member, USSR Academy of Sciences), Teoreticheskiye voprosy sovetskoi zakonnosti, SoVETSKOYE GOSUDARSTVO I PRAvo, No. 4, at 15 (passed for publication on June 22, 1956).

73. Cf. RuDolpH Schlesinger, SoVIET LegaL THEORY $4 \dot{3}$ (1945). For an unusually frank, unembellished comment from a DDR source, see KIENNER, FoRMIEN UND BEDEUTUNG

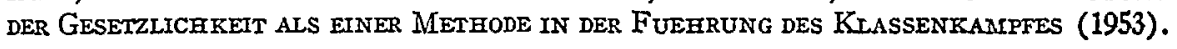


the sovereign role of the Communist Party, which to him was the only revolutionary instrument conceivable under the laws of history. The supremacy of the party as the sole fountain of "objectively correct" thought and action was not to be questioned. Whatever the function of socialist law emanating from the revolutionary government, no legal norm was ever to supersede party decisions.

True, requirements of central coordination and disciplined procedure necessitated upholding the validity of unacceptable legal norms not yet formally abrogated or revised. The legislative prerogative of governmental institutions was to be retained, at least in theory. But even in Lenin's lifetime, rigorous procedural simplification of law-making to suit party needs made short shrift of the sanctity of law and reduced to naught whatever hesitant rloctrinal attempts were undertaken to place the law, once promulgated with the party's approval, above shifting party decisions.

Later, during the three decades of Stalin's increasingly one-man rule, the art of interpretative distortion and retroactive revision of expectedly authoritative pronouncements was developed to a high point. Based on Lenin's teachings about the role of the party in the revolutionary process, an elaborate body of doctrine was constructed to establish the all-pervasive quality of the principle of partiinost ${ }^{74}$ This principle comprehended the unassailable primacy of party decisions, the inalienable authority of the party as the supreme arbiter in conflicts of ideas, and the all-embracing nature of the adherent's commitment to the party.

Party supremacy permitted the Soviet government to turn the balance of social power upside down and, more than once, to revamp its basic economic structures. When the uprooting of millions of people generated social malaise, always a threat to production, when, time and again, the Soviet government found itself on the lookout for stabilizing factors, the authority of the law was reinforced and greater importance attached to the historical mission of, and the element of objective necessity in, socialist legality. Doctrinal disquisitions on the law's lasting normative validity mushroomed.

Just such a climate prevailed in Russia after the 1956 Twentieth Congress. "Mistakes" committed in the Stalin era were denounced and the sovereignty of law was emphatically espoused. Restoration of legality became a mandatory topic in the official journal of legal doctrine. ${ }^{75}$ In the issue sent to press on May 4, 1956, the turn was signalled by Soviet Prosecutor General Rudenko in person. "In the light of the decisions of the Twentieth Congress," legality was to become the focal point of all endeavor in the legal sphere. ${ }^{76}$ More

74. See explanation given in note 1 supra.

75. SOVETSKOYE GOSUDARSTVo I PRAvo, published by the A. Ya. Vishinskii Law Institute of the U.S.S.R. Academy of Sciences.

76. Rudenko, Zadachi dal'neishego ukrepleniya sotsialisticheskoi zakonnosti $v$ svete reshcnii XX s'yezda KPSS, 1956 SovetsKoYe Gosudarstvo I PRAvo, No. 3, at 15. Rudenko is a candidate member of the Central Committee of the CPSU and a member of the USSR Supreme Soviet. 
specifically, the chief prosecuting official indicated that still greater emphasis would be placed on the work of the prosecutors' offices, principal custodians of legality. ${ }^{77} \mathrm{New}$ legislation in the area of substantive criminal law would ease the prosecutors' job. Laws, in the future, should be made only by legislative bodies assigned this function by the Soviet Constitution. While there was no reason to downgrade decisions of the USSR Supreme Court, it was essential to stress that the court was without power to enact new legal norms or directives the equivalent of statutes. ${ }^{78}$

$\mathrm{Six}$ weeks later, the (delayed) next issue of the journal carried a declaration of theoretical principles in which lack of legal security in everyday life was directly linked with Stalinism:

An important cause of violations of legality in the past was the cult of personality. Personality cult is incompatible with the consistently maintained legality, for it creates a climate which obstructs vigorous observance of the law and fosters the tendency of individual law-enforcers to place themselves above the law instead of obeying it without reservations as legality demands. ${ }^{79}$

True devotion to legality was missing in Soviet life. Many even invoked Lenin's authority to justify making observance of the law dependent on considerations of usefulness and expediency. But such considerations "can only imply the useful application to a given case, in conformity with the law of a provision authorized by law; [they] cannot imply circumvention or violation of the law."so

Following the lead of the Prosecutor General, ${ }^{81}$ the journal blamed Soviet legal theory for having neglected problems of legality. In particular, it attacked the allegedly "dialectical" denial of the validity of legal norms by the top legal authority of the bygone Stalinist era, who had asserted that the "dialectical approach to law interpretation precludes stereotype interpretation and stereotype application of legal norms." ${ }^{2}$ Not "flexibility" but "unbending rigidity" must be displayed in the enforcement of statutes. Participants in a 1954-1955 discussion were castigated for having defended "flexible" attitudes:

Theses absolutely incompatible with actual implementation of legality are sometimes offered on the pretext that it was necessary to combat formalism in the application of the law, or that the law had to be treated dialectically. Whenever it accepts this, the science of law, instead of fighting for the strengthening of legality, embarks on the dangerous venture of laying the theoretical foundations for permissible departure from the law. ${ }^{83}$

77. Id. at 17.

78. Id. at 20 .

79. Strogovich, supra note 72 , at 16.

80. Id. at 17 .

81. Rudenko, supra note 76, at 18.

82. Denisov, TeOriya gosudarstva I pRava 480 (1948).

83. Strogovich, supra note 72 , at 20 . 
Many a reiteration followed. By the end of 1956 an editorial restatement of immediate objectives once more spelled out the implications of the Twentieth Congress's stand on legality. The editors urged the active defense of the rights of Soviet citizens, the correction of "the most flagrant violations of Soviet legality" that had grown out of the "cult of personality," improved legislation, the codification of existing law, better training of judicial personnel, and clear demarcation of overlapping jurisdictions. 84 Then the tide changed and the topic was abruptly dropped from the columns of the official law journal.

A different mood prevailed when the discussion flared up anew in March 1957. Violation of legality was no longer the subject of grave misgivings. What now disturbed the rulers' peace of mind was the apprehension that all legal norms might be held sacred by the uninitiated. Clarification was supplied in a signed editorial by the associate chief editor.

On the whole the Communist Party and the Soviet state express correctly (in legislative acts) the people's conscious thinking; but this does not imply that every normative act always automatically, as it were, provides an adequate solution to economic requirements that must be met, nor that every such act expresses exactly what the people thinks . . . . Legal studies, however, have been prone to lift on the shield any judicial decision, even many an incorrect one, and any legislative act, including such as had to be rescinded later because of their temporary, transient nature or because they had been erroneous; theoretical justifications have been construed to prove that such decisions and acts have been correct and in accordance with the interest and will of the people.

Because this objectionable practice defied Lenin's teaching, its discontinuance was urged. 85

Harping on the mistakes and excesses of the Stalinist era was abandoned, and the rights of the individual were no longer in the foreground. The party's stand on law and legal order once more was shifting. Another blackout followed. Then the atmospheric change came into plain view, as so often happens in the totalitarian realm, in a peripheral piece of doctrinal polemics. Made up as a special feature, a critical broadside was hurled by a writer of little renown ${ }^{\text {st }}$ at the very same scholar who the year before had been commissioned to expound the anti-Stalin theory of legality. This scholar's 1956 book on procedural law and the evaluation of evidence in criminal trials ${ }^{87}$ was severely criticized for having undialectically drawn a line between the "material truth" "if factual evidence and the relative validity of judicial evaluation. The dialectical approach, so recently and vigorously condemned, was en vogue again.

84. Editorial, Dal'neisheye ukrepleniye sotsialisticheskoi zakonnosti, 1956 SovErSKoYE 6osundkstvo 1 PRaYo, No. 10, at 3 (printing authorized Dec. 11, 1956).

85. Bratus, Uchit'sya u V.I. Lenina resheniyu teoreticheskikh $i$ parkticheskikh voprosov prava (Editorial), id., April, 1957, at 3, 6.

86. Kiv lin, Zalownost' $i$ istinnost' sudebnogo prigoziora, id., July, 1957, at 114.

87. Strugin'feh, Material'nala istina I sudebncye nokazatei'stvo V sovetskom UGOLOVNOM PROTSESSE 1956. 
The last touch was applied-not very gently-in an editorial denouncing the "antiparty activity" of Kaganovich, Malenkov and Molotov. "Strengthening of socialist legality" was no longer the focal theme. The headline slogan, once again fed into courtroom loudspeakers, clamored "for the strengthening of the Socialist Soviet State under the leadership of the Communist Party." 88 The party, hitherto unmentioned in discussions of the doctrines inaugurated at the Twentieth Congress, re-emerged overnight as the sole architect and custodian of socialist legality. ${ }^{89}$ On behalf of Soviet juridical science, the editors of the law journal took a solemn oath to obey the decisions of the Twentieth Congress and carry on unwaveringly the fight against the "luckily unmasked antiparty group." This, however, was not enough; the science of law "still owes the party a tremendous debt." "Scholarly juridical literature has presented but weakly, and has failed to expound elaborately, the directing of the Communist Party in the construction and functioning of the state, and ... as the living foundation of Soviet legal and governmental institutions and processes." The jurists must do their utmost to redeem this onerous debt."

Thus, the widely publicized stress on the role of legality had evaporated. Official recognition was again given the party's role as the "living foundation" of law and government. Although the contents of the new rules might well continue to mark important departures from Stalinist practices-witness the new criminal code- the rank order of the party as initiator, motor and regulator of social processes and the legal order as an implementing device emphatically was reconfirmed. ${ }^{91}$

In other countries of the Communist bloc, these gyrations of Soviet doctrinal thought were echoed resoundingly but not followed precisely. What reaches the consumer at the end of the line is not necessarily a true copy of the original. Even in the DDR, a faithful adapter, stereotypes already discarded and replaced in Moscow are used simultaneously with brand new ones. The ensuing confusion tends to make life under the DDR regime uncertain and unpredictable.

Percolating into DDR jurisprudence with little delay, the Soviet legality course with its apologia of the supremacy of law became the official doctrine by spring 1956. But only briefly, for the Soviet Union was to shelve it within less than a year. Still, some legality enthusiasts found enough time to procede so far as virtually to repudiate the principle of partiinost' (or its German partyslang equivalent, Parteilichkeit).

88. Editorial, Pad rukovodstvom Kommunisticheskoi partii za dal 'neishcye ukrcpleniye Sovetskogo sotsialisticheskogo gosudarstva, SovETSKoYE gosudarstvo I PRAvo, Aug., 1957, at 3.

89. Id. at 8-11.

90. Id. at 10 .

91. This, however, should not be taken to imply definite abandonment of legality teachings. It may be taken for granted, for example, that new emphatic admonitions to observe legality will accompany the turbulent rebuilding of rural party and government structures set in motion with the abolishment of Machine and Tractor Depots (MITS). 
The most extreme of these views ${ }^{22}$ implied that, inasmuch as socialist legality expressed objective requirements of the historical process, it necessarily limited the choice of ways and means appropriate for attaining society's goals to those encompassed by established legal norms. In the light of this doctrine, rules of action should be drawn from normative acts passed by the Government's legislative bodies rather than from ad hoc decisions of party bodies. Correspondingly, judicial interpretation would not be identical with ensuring that law, or the rationale of its application, met party specifications in the individual case before the court. Partiinost', under such a theory, could no longer override the law. It would have to be regarded as inherent in the legal norm, a quality imparted to the normative act in the lawmaking process by virtue of the fact that the legislators represented the party in translating the objective laws of social development into rules applicable to specific situations.

Clearly, this reasoning stripped the party of the power informally to cast overboard legal norms no longer to its liking. If a legal norm proved a dead weight because the legislators had misread history's "objective" requirements or had miscalculated the malleability of social reality, it was up to the legislative bodies to remove the discrepancy by changing the law. ${ }^{93}$ Intended to curtail the arbitrariness of party interference, this interpretation disregarded possible arbitrariness on the part of the lawmaker. It is indeed conceivable that the lawmaker, concerned with his own prestige and position, would, though fully

92. See Artzt (Director, DDR Institute of Civil Law), $Z u$ einigen Fragen der sozialistischen Gesetzlichkeit in der Deutschen Demokratischen Republik, 10 N.J. 581 (1956), where the principle of legality finds consistent affirmation from what may be termed an "objectivist" or "positivist" point of view. Artzt meanwhile has duly recanted his errors. He admitted that his teachings as to "a certain independence of the law" and its separation from the politics of the party are in contradiction with the Marxist-Leninist theories of state and law. StaAts und Rechtswissenschaftziche Konferenz in Babelsberg am 2 \& 3 Mar 1958, at 154 (1958).

Of the scores of Soviet and satellite papers on legality that have been translated for DDR publications, only a few betray an "objectivist" viewpoint. Strongly pointing in this direction are two papers by Kerimov, Fragen der Theorie der sozialistischen Gesetzlichkeit, 11 N.J. 385-390 (1957), and Die wissenschaftlichen Grandlagen der Rechtsschoepfung des Sowjetstaates, in 6 STAAT UND RECHT 580 (1957), both adapted from his Zakonodatel'naya deyatel'nost' Sovetshogo gosidarstva (1955), a beginner's theoretical inquiry into the legal structure of Soviet legislative processes, which drew heavy fire during the short-lived era of legality raptures. See 1956 Sovetskove cosudarstvo I PRAvo, No. 5, at 95-96, 129, 132 No. 9, at 9. A premature forerunner of the 1956 campaign, Kerimov had considerably overshot the mark. What was worse, he then misjudged the meaning of the elaborate dressingdown he had taken. While tuning down, for the German version, the "objectivist" theme, he unperturbedly went on disparaging lawmaking by agencies not constitutionally empowered to legislate. As bad luck would have it, his re-emphasized demand that the legislators-and they alone-be the ones to correct faulty legislation came out in Germany just in time to clash with Moscow's renewed oath of allegiance to the party as the "living" sovereign above the law.

93. Kerimov, Fragen der Theorie der sozialistischen Gesetzlichkeit, 11 N.J. 385, at 387 (1957). 
aware of the discrepancy between norm and reality, nevertheless fail to "put socialist law in step with life," intransigently use the unrealistic norm as a whip, and insist on norm-prescribed goals beyond the social energies already harnessed. Who then would correct the lawmaker?

For obvious reasons, enthusiasm for legality in this extreme form conflicted with the party's traditional philosophy, in that "historical necessity" here appeared "objectively" expressed by legal norms, not by party action. Essentially, however, the new doctrine substituting the legislative for the party machine, merely exchanged one institutional agent of "historical necessity" for another. The agent, whatever its designation, was still ascribed a mystical mission in the pursuit of an abstract society's presumed goals, which in turn were assigned an infinitely higher rank than the interests of individuals who make up the actual and immediate society.

Still, when legality, no longer seen as a mere shorthand code for class rule, stands for concrete programs of social and economic action, the individual is bound to slip in through the back door. When the law serves as the chosen instrument for making wide-range governmental plans come true, the activity of the individual must be planned as well; to fulfill plan objectives, the individual must have some latitude of action, at least within a sphere circumscribed by the plan. If he remains passive, actual achievement will fall short of plan objectives. Accordingly, the individual is theoretically granted certain prerogatives. But, in so far as his area of freedom is wholly directed toward plan objectives, these prerogatives shrink in practice.

The struggle for the fulfilment of plan objectives, varying but never relaxing, holds an entrenched priority. The prime concern of the party and government is to overcome all conceivable resistance to the overall program, whether it originate in recalcitrant moods, individual entanglements, inadequate understanding of objectives, or any other retarding factor rooted in the given social situation. The legal order adapted to this central policy requirement does not emphasize protection of the individual against loss of freedom, judicial restraints on administrative action, legal buttressing of private positions, or guarantees for droits acquis.

Technological, organizational and manpower bottlenecks constantly delay and endanger the attainment of objectives set by party and government decisions. Naturally enough, those in power are reluctant to multiply such impediments by lending support and privilege to private interests (with the exception, of course, of those interests disguised in terms of office authority and public title). To be sure, individuals may file complaints with hierarchic superiors and the prosecutor's office will accept requests for the review of allegedly illegal administrative decisions. ${ }^{94}$ But beyond these measures, no legal remedy to preserve the rights of the individual against the administrative

94. DeUtsches Institut fUR Rechtswissenschaft, DAs VerwaltungsRecht der Deutschen Demokratischen Republik, Allgemeiner Tell 197 (1957). 
machine exists. Legal norms to protect such rights will remain a dead letter so long as there are no organized social groups to compel enforcement. In pluralistic societies, norms become effective to the extent they create subjective rights that individuals or groups find advantageous to invoke and, if necessary, uphold in organized action. The interplay of individual, group and governmental interests competitively determines the selection of norms to be enforced. While the choice hinges on the relative strength of the interests affected, the function of interpreting disputed norms devolves upon an independent arbiter. Presumably removed from the interests involved, the judge is expected to apply standards free from unilateral change by a party to the dispute.

Free competition of ideas and social forces is anathema in a society that outlaws voluntary organization and substitutes centralized planning and direction. There, the individual has little chance actively to invoke the protection of the law, and governmental authorities are the only ones to decide which norm is to be operative. The abstract thesis that every norm, once enacted, must be enforced as part of the all-embracing plan of social improvement will not apply in the absence of organized pressure to protect even those rights that interfere with the government's monopoly of action. Only a few areas of norm enforcement are within the individual's reach, and those are mostly in interpersonal relations. More recently, however, a narrow path has been opened through which a few individuals can squeeze into the restricted area where personal freedom is protected from physical encroachment by government agencies. ${ }^{95}$

The government, whose attention remains fixed on plan objectives, determines the vigor and intensity with which any chosen legislative program is made to operate in everyday life. By so doing, the central administration avoids relegating a wide area of choice to individual departments or regional agencies, which as a rule are less conscientious and tend to neglect a number of central projects, especially those that add to their administrative and propaganda chores. ${ }^{96}$

Is the focal emphasis, if not the very content, of the norm enforcement changes, the significance of "legality" becomes less evident. The gyrations must then be rationalized in terms of legality's shifting content. In actual practice, varying clusters of norms are designated from time to time as "points of concen-

95. This field concerns stricter enforcement of the rules governing preventive detention of defendants awaiting trial and preliminary arrest. Intrabureaucratic controls were strengthened in 1956. Melsheimer, Unsere Staatsanwaelte sind Hueter den sozialistishent (irzetzlichkeit, 10 N.J. 225, 226 (1956); Melsheimer, Sozialistische Gesetzlichkeit in Strafz'erfahren, 10 N.J. 289, 291 (1956) ; Herrmann, I'oranssetzungen fuer die Anordnung der l'ntersuchungshaft, 10 N.J. 392 (1956).

46. Official opinion contends, for example, that plans for setting up a giant corps of lay judges met with wide-range apathy at the lower level-that is to say, among municipal and union officials and local magistrates-and that only unrelenting perserverance on the part of high judicial authorities made it possible to effectuate the plans. Benjamin, $Z u$ Jrage'n der Gesctzlichkeit und der Leitung innerhalb des Justizapparates, 9 N.J. 387 (1955). 
tration" on which law enforcement must be stressed. ${ }^{97}$ This is part and parcel of the legal setup as it affects both administrative implementation and judicial interpretation of the law, provinces largely overlapping in the framework of socialist legality. The formula, "changing content of legality," entails variations in the sets of norms singled out for preferential enforcement as well as interpretative changes in the meaning of specific norms.

The East German version of the Russian accent on legality, whatever its suspect doctrinal fruit, has not abounded in practical conclusions. As early as May 1956, when the cult of legality blossomed out in Moscow as a byproduct of de-Stalinization, East Berlin developed an ingeniously simple formula for combining lip service to legality with a rescue operation to salvage the primacy of nonlegislated norms of unidentified origin. Addressing a national conference of judges and prosecutors, DDR Premier Otto Grotewohl stated that "democratic legality consists not only of the observance of existing written law but also of the fact that whatever makes up our socialist standard of right [unser sozialistisches Recht], and increasingly will be expressed in our statutes, is now already being put into effect." 08 Adjustment to policy changes, however radical, presents no troublesome ideological problems when whatever is "put into effect" makes law.

\section{"Socialist Legality": Adaptable Practice}

In DDR judicial practice, the notion of legality has taken variegated forms. Until 1953, there were unmistakable efforts to bring as many types of factual situations as possible under the scope of article 6 of the DDR Constitution, which penalizes inciting the "boycott" of democratic institutions and organizations, instigating the assassination of democratic politicians, committing other acts "directed against the principle of equality," and expressing religious, racial or national hatred, or militarist propaganda. Instead of enumerating and defining categories of reprehensible political acts, this catalogue supplies defamatory labels and relies upon the discretion of the courts to pin an appropriate name on any individual suspect as inimical to the regime, and to impose any of the penalties, ranging from a fine to the death penalty, that the Criminal Code provides. For example, the code was invoked to penalize, under a Soviet military administration order, the attempted removal of corporation assets to West Germany. ${ }^{99}$ A "piece of clearly discernible war propaganda" punishable under the code was seen in "idle talk of Jehovah's Witnesses," 100 who thus

97. Present points of concentration are: increased labor productivity, protection of socialist property, and furtherance of the socialist transformation of agriculture. See Melsheimer, supra note 58 , at 513.

98. Neues Deutschland, May 20, 1956, p. 1.

99. High Court Judgment of Feb. 28, 1951, 1 Entscheidungen des Obersten Gerichts in Strafsachen 104 (1952).

100. High Court Judgment of Feb. 12, 1952, 2 Entscheidungen des Obersten Gerichts in Strafsachen 7 (1953). 
faced under the DDR regime a treatment scarcely less ferocious than the one they had suffered under the Third Reich. During the Korean conflict, "1utterances of national hatred" were discovered in rumors about the fate of soldiers taken prisoners by the North Koreans. ${ }^{101}$ A case arising from a brawl at a social gathering, in the course of which a Communist was hit for having ranted against "American dancing," was remanded to a lower court for possible application of article 6 on the grounds that, "claiming to have been drunk or suffered insults, enemies of the established order use the slightest provocation brutally to assault holders of public office." 102

This unmitigated prosecution of actual or imaginary enemies suffered a major setback in June 1953, when the DDR government, belatedly drawing conclusions from the political change which had taken place in the Soviet Union after Stalin's death, inaugurated a "new course." Announced early in June, the liberalization program was carried beyond its limited objectives by the force of general unrest culminating in the popular uprising of June 17. Minister of Justice Max Fechner, subsequently dismissed for excessive liberalizing zeal, took sensational steps to prove the sincerity of the new spirit. In the course of five days-June 15-20-the administration of justice wallowed in a true orgy of clemency: 2,427 detention orders were cancelled, 1,484 convicts paroled, 1,363 cases held not to merit prosecution, and 927 cases returned by the courts to the prosecutors' offices for a nolle prosequi decision. ${ }^{103}$

Mass application of $\mathrm{nol}$. pros. dismissals merits special attention as a feature of "socialist legality." Certainly, the nol. pros. technique is not uncommon in most legal systems. It is principally applied when the prosecution considers the reprehensible action too unimportant to warrant trial, or too inconsequential when viewed against the offender's personal background to justify sanctions which would blot his record. While such benevolence-or just common sense in human relations-may wipe out the consequences for the offender, it will not make black white nor erase the fact that an unlawful act has been committed. Yet this is precisely what DDR jurisprudence seeks to achieve.

Following the model of the USSR Penal Code, DDR jurists have developed a concept of offense which, in a way, equates the criminal act with its consequences for society. Even though all subjective and objective elements of a criminal act are present, established judicial doctrine refuses to treat the incriminating action as an offense unless it entails specific danger to society. The existence of this danger may be denied because of the insignificant nature of the interests infringed upon, or because no harm ensued. for society as a whole, or, because-characteristic twist-either society had changed in such a way as to make the still prohibited act socially innocuous or the offender had

101. High Court Judgment of Dec. 7, 1951, 2 Entscheidungen des Obersten Gerichts in Strafsachen 283 (1953).

102. High Court Judgment of Dec. 9, 1952, 7 N.J. 25 (1952).

103. See Fechner, Der neue Kurs der Regierung und die Aufgaben der Justiz, 7 N.J. 381 (1953). 
experienced so radical a reversal of his personality structure as to purge the perpetrated wrongdoing of its criminal characteristic. ${ }^{\mathbf{1 0 4}}$

The spy who, in redeeming himself in the eyes of his accusers, has erased his offense is among the examples most frequently cited to illustrate that transformation of personality which erases the criminal nature of the initially prosecuted act. To be sure, the renegade spy turned state's witness will be compensated in one way or another, more often than not in a left-handed way, by any political system that benefits from his "conversion." But hardly anywhere will love of the turncoat informer reach the point of ascribing to him, as does this concept of justice, a moral metamorphosis so sweeping in nature as to engulf his misdeeds.

The underlying doctrine, which revolves around the "material concept of the offense," serves the rulers as another tool to punish enemies and reward friends. In individual instances, it permits the relaxation of an overly harsh system of criminal law; it shields beneficiaries of the power setup from the fangs of the law; and it marks the intrusion of unadulterated arbitrariness into criminal prosecution. Affecting all decisions to withhold the prosecution of acts punishable under the law, this doctrine jeopardizes legality at one of its most sensitive spots. ${ }^{\mathbf{1 0 5}}$

The original Soviet teaching-that danger to society is an essential characteristic of the criminal act-has been subject to criticism in recent debate in the Soviet Union and other countries of the Soviet bloc. ${ }^{106}$ In the DDR, it still provides the doctrinal background, in many instances, for refusal to prosecute. The converse doctrine, applied as frequently but serving the opposite purpose, is one of extreme penalization. By this theory, the State holds a defendant criminally liable for socially damaging consequences of his action regardless of subjective guilt. Combined, these doctrinal constructs may serve as a perfect switch for turning criminal sanctions on and off ad lib. Their contribution to strict observance of legality is as dubious as that of the hodgepodge of opprobrious labels in article 6 of the constitution.

An abortive attempt to limit the applicability of article 6 was undertaken in the early days of 1953's "new course." Treading rather cautiously after the revolt had been crushed by Soviet tanks, the SED central committee decided on June 21 that, in the prosecution of the rebels, a distinction should be made between instigators and passive participants inadvertently swept along by the mainstream of events. Minister of Justice Fechner thereupon decided that

104. For official definitions, see DeUțChes INSTItUT FUER RECHTWISSENSCHAFT, op. cit. supra note 33 , at $254,266$.

105. Interesting parallels in Nazi practice have been pointed out by LaNGE, DIE Anwendung des Sowjetischen Strafrechtes nach Ingatt und Forar in der sowjetzonalen Praxis, EntwickuUngen des Sowjetstrafrechts und sein Einfluss auf DIE ReChTSPRECHUNG IN DER SOWJETzONe 55 (1956).

106. Cf. Maurach, Zur Entwicklung des materiellen Verbrechensbegriffs im sowijetischen Strafrecht, 1 RECHT IN OST UND WEST 137 (1957). 
participation in strikes aimed at economic objectives, conduct which had provided the background for the uprising, did not fall under the purview of article 6. The High Court and lower Berlin courts followed suit in sentences meted out in the latter part of June. ${ }^{107}$ The Minister himself was removed from office in a matter of days, however, and arrested. ${ }^{108} \mathrm{He}$ was denounced as an enemy of the State for having shielded behind the protective mantle of a justifiable strike a conspiracy to overthrow the "democratic order." The courts at all levels thereupon began turning out assortments of ruthlessly severe sentences. They cooperated fully with the newly-appointed Minister of Justice, Frau Hilde Benjamin, who was to declare with braggadocio that "the judges had learned within a few days" how to apply the central committee's distinction between enemy agents and misguided but basically decent worker participants in the June events. ${ }^{109}$

Reprisals did not clarify the Government's intentions. The dismissed head of the judiciary was blamed by his successor both for leniency toward enemies of the State and for inexcusably harsh judgment; he was also accused of having fostered violations of legality. ${ }^{110}$ The new Minister of Justice and the High Court took pains to explain reprisals against the June rebels as a special emergency measure which in no way detracted from the "new course" as set forth by the DDR cabinet on June 11.111 Specific legal implications of the liberalizing line were not spelled out.

In actual practice, administration of justice continued zigging and zagging until the spring of 1956. Enforcement of discipline through "educational" pressure vied with disciplinary reprimands and the much severer arsenal of sanctions imposed by special legislation or derived from the cure-all provisions of article 6. At the highest level, efforts were made to have the courts observe rather subtle criteria for distinguishing individual lapses calling for disciplinary correction or lesser penal sanctions from deliberate acts undermining the

107. High Court Judgment of June 30, 1953, 7 N.J. 410 (1953) ; Berlin Municipal Court Judgments of June 23, 24, 25, 1953, Berlin Appeal Court Judgment of June 26, 1953, 7 N.J. 421 (1953).

108. Fechner was released from prison in 1956 and received a handsome indemnity for his unwonted sufferings.

109. Benjamin, Unsere Justiz-ein zeirksames Instrument bei der Durchfuehrung des neuten Kurses, 7 N.J. 477, 479 (1953).

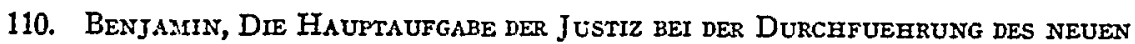
KURSES. UbERARBEITETES UND ERGANZTES STENOGRAMIM EINER REDE, GEHALTEN VOR FUNKTIONAEREN DER JUSTIZ AM 29. AUGUST 1953, at 24 (1953).

111. The DDR Law Journal carried only a few writeups of the cruel sentences imposed by the court on participants in the June events. And the DDR High Court, assembled in plenary session on August 29 , even set aside a previous judgment of one of its sections and said that the sentence had been unnecessarily harsh and application of article 6 unlawful, for its provisions must not be invoked in cases other than those of "direct interference with the public order." See 3 Entscheidungen des Obersten Gerichts in Strafsachen 99, 102 (1954). 
foundations of the State. In point of fact, however, decisions as to what sets of sanctions should apply depended as before on the magistrates' state of mind and the pressures and campaigns to which they were exposed, rather than on the character of the offense or the situation of the offender. ${ }^{112}$

Increasingly, the courts were directed to combat the continuing exodus from the DDR. While migration to West Germany was not punishable per se ${ }^{113}$ and indirect prosecution was possible only in cases that involved violation of interzonal trade regulations, "boycott" provisions under article 6 were invoked against citizens who instigated the moves, those "who know that every member of the labor force is urgently required for the expansion of the peace economy."114 A lower court went so far as to apply this provision to a lady fortune teller whose readings were alleged to have inspired her customers to leave the DDR. ${ }^{115}$

All this changed suddenly, if temporarily, in March 1956, when the spirit of reform espoused by the Twentieth Congress of the Soriet Communist Party began to touch East German society through the medium of the Third Party Conference of the SED, held March 24-30, 1956. ${ }^{116}$ Socialist legality became the slogan of the day. Critics were permitted to say that the "new course" of 1953 had not been consistently steered. The party was urged to abandon "inordinate over-emphasis on governmental authority" and the pretense that the judiciary was "absolutely infallible." Minister of Justice Benjamin was later to say that, "as a consequence of the erroneous doctrine of the exacerbation of the class struggle, emphasis on the application of this or that norm shifted repeatedly." She added: "While we

112. Comments by Walter Ziegler, High Court Vice-President, summed up practical advice for the courts on when to apply article 6, and incorporated certain trends which had crystallized by that time. Ziegler, Verbrechen gegen die Deuische Demokratische Republik, 9 N.J. 677 (1955). For example, the time had come to dispel the doubts that had prevailed in the fall of 1953 with respect to pressure in favor of collective farms which might be exerted on farmers and rural officials. By 1955 even lower courts saw "sabotage" under article 6 in such crimes against collective enterprise as collective farmers" private animal holding in excess of a fixed ratio, together with use of collective farm produce for feeding such "excess" animals, or unsterile vaccination by a veterinarian of livestock owned by a collective farm. Reports on such lower court rulings in April and June 1955 were reported in 9 N.J. 417-18, 504-05 (1955).

113. Not until December 1957 was unauthorized departure from the DDR made a punishable offense regardless of destination. See text accompanying note $135 \mathrm{infra}$.

114. High Court ruling of Jan. 27, 1956, 10 N.J. 99 (1956).

115. Judgment of the District Court of Suhl, Thuringia, April 16, 1956, 10 N.J. 479 (1956).

116. Between national congresses which meet once in three or four years, the SED holds "conferences," in which the party's governing and functional bodies meet with regional and district bosses.

117. Schulze, Neve Masstaebe, 10 N.J. 645 (1956). Schulze, the most outspoken inside critic of governmental policy, was to be severely reprimanded in 1957 for his critical exploits of 1956. The editors of Neue Justiz were harshly upbraided for having published Schulze's attack on the party and legal leadership. 
kept within the framework of the law, we still violated legality."118 On a number of specific issues, governmental policy was radically reversed. 119

Had the jurists and the party authorities seen the light overnight? Was legality more than just a way to find a peg-called norm-on which to hang whatever rules were slated for confirmation by the courts under the latest government instructions as to desirable attitudes? Had criminal law a special job to perform in society, or was it merely a faint echo of the class struggle? The Twentieth Congress had explicitly rejected Stalin's contention that the class struggle was bound to become more intensive and ruthless as a result of the establishment of the "foundations of socialism in the USSR." Since too great significance had been attached to the role of criminal law in the regulation of human conduct, the importance of criminal sanctions was de-emphasized.

Accordingly, DDR legal theorists now found that, while criminality was related to class struggle in the infinite chain of causal links, many violations of the criminal law mirrored nothing more than social relationships in which human beings conducted themselves as individuals rather than as representatives of class interests or class positions. Offenders who committed unlawful acts as a result of personal entanglements neither visualized nor cared about the effect of their actions on specific class situations. Accordingly, they should not be held liable for consequences prejudicial to the conduct of the class struggle. ${ }^{120}$ Views of such an extreme deviationist slant were vented and discussed in the course of a 1956 public debate on class struggle and the criminal law.

Applied to political jurisprudence, such views posed dangerous implications. The scope of the crucial article 6 would be narrowed down to acts intentionally directed at the overthrow of the DDR regime. Those guilty under the erstwhile official interpretation of various articles 6 offenses-for failure to meet approved standards of "class consciousness"-could no longer be prosecuted. It would then be virtually impossible to designate as enemies of the commonweal, punishable under article 6 regardless of motives and degree of involvement, persons merely guilty of having run afoul of regulations cover-

118. Benjamin, Fragen des Beweisrechts in Strafprozess, in DEUTSCHES INSTITUT FUER ReChtswissenschaft 107 (1957).

119. The fortune teller's contribution to "escape from the Republic" was dismissed with contemptuous irony. The High Court quashed the judgment of a lower court which had sentenced a public transport white-collar employee with good professional contacts in Western Germany for having advised fellow workers to move to the Federal Republic where, according to his information, they would fare better. Nor did the High Court find any "elements" of a hostile act in the defendant's view that every hour one remains in the DDR was wasted time. See High Court Ruling of Nov. 2, 1956, 10 N.J. 766 (1956). But a year later, when the political climate and policy towards flight from the DDR changed again, the ruling became "wrong and detrimental." Haid, Einige aktuelle Probleme der staatsanzwaltschaftlichen Arbeit, 11 N.J. 794, 797 (1957).

120. For a summary presentation of this train of thought, see Schuessler, Uber Rechtsverletzung und Klassenkampf in der Deutschen Demokratischen Republic, 5 STAAT UND RECHT 825 (1956). 
ing the delivery of farm produce, an increase in work quotas, or an embargo on emigration.

Predictably, the liberal deviations of 1956 were soon repudiated. The Soviet bloc's misfortunes in Hungary hastened the resumption of repressive policies. Those who had questioned the omnipresence of the class struggle in the realm of criminal law were castigated. Among other things, they were told that it would be impossible to maintain strict standards of legality unless the criminal act as such were penalized, irrespective of subtle differences between political hostility to the established system of government and other asocial attitudes. In addition, the all-pervasiveness of the class struggle was vigorously reasserted.21 Delaying or obstructing the attainment of society's objectives, every criminal act was bound to influence class relations no matter what the perpetrator may have had in mind. Intentions and motivations mattered as little as did the defendant's social background; the concrete facts alone would determine the category of charges to be preferred. ${ }^{122}$

Formal reappraisal of 1956 's liberal positions also followed in the wake of the Hungarian uprising. In January 1957, the thirtieth plenary session of the SED Central Committee condemned the doctrine that had viewed spontaneity and economic self-government as stages in the "withering-away of the state."123 It also criticized mistakes in the judicial implementation of decisions by the Twentieth Congress and the Third Party Conference of the SED, and deplored the fact that less harsh judicial and penal practice had resulted in flagging vigilance for reactionary and imperialist subversion. On March 9, the "boycott" provision of article 6 was invoked to convict a party ideologist for the attempted rerision of party principles and alleged efforts to establish contacts with Social-Democrats. ${ }^{12 \pm}$ The judiciary was sternly admonished to heed "warning signals" from the "working class," reportedly indignant over the recent leniency in sentencing policy. ${ }^{125}$

During the summer months of $195 \%$, even more persistent criticism was directed at "liberalism" and "subjectivism," judges were taken to task for failing to study the debates and conclusions of the January meeting of the

121. "A simplified and vulgarized class struggle discussion" was the verdict of Attornes General Ernst Melsheimer when drawing up his list of particulars against the recent "revisionism." Melsheimer, Das Strafrechtsergaensungsgesetz-iin Gesetz dor sozialistischon Demokratie, 12 N.J. 42 (1958).

122. Klassenkanipf und Strafrecht. Protokoll einer Tagung dek Abtellusg Strafrecht des Deutschen Institcts fur Rechtswissenschaft in Beris ai 16. NOVEMrber 1956 (1956).

123. The time apparently had come to make use of the formula prematurely coined by Minister of Justice Benjamin the year before, which invited the courts "to make decisions independently from local influences but without underestimating local points of concentration of the class struggle." Her speech of April 16, 1956, is reported in 10 N.J. 259, 260 (1956).

124. See excerpts from the Harich judgment in 11 N.J. $166-70$ (1957).

125. Editorial, Nach dem 30. Plentm des Zentralkomitees der $S E D, 11$ N.J. 129 (1957). Criminal law theoreticians then worked overtime to show the dangers of subjectivism in criminal law and to draw up an impressive list of early culprits, starting with von Liszt. 
central committee thoroughly enough. The principle of "Parteilichkeit" 126 in judicial decisions was given new emphasis and was distinctly contrasted with "methods of interpretation based on formal logic."127 In October 1957, SED boss Ulbricht once more endorsed the widest possible application of article 6 in redefining the area of freedom in the DDR. Freedom, in this version, ends "where an action benefits NATO and Western revenge mongers or violates the laws of the Republic."128

By late spring 1958, "impartial" application of the law had become the deadliest reproach which might be levied against a member of the judiciary, and "Parteilichkcit," together with the fight against revisionism, was the password on everybody's tongue. Legality, while not entirely smothered in theory, now is invariably coupled in an indissoluble "dialectical unity" with "Parteilichkeit."'129

The end of the 1956 trend resembled a rout. The treatment given the draft of a reform of criminal procedure submitted by a special commission appointed at the height of the liberalization wave was characteristic. The Minister of Justice went so far as to deny that any basic reforms had been included in the commission's terms of reference. The need for a revision of criminal procedure was refuted point by point. Among the public's major grievances had been the persistent use in trials of testimony given before the police, a practice based on section 209 of the Code of Criminal Procedure. This section implied that, in the event of discrepancies between a defendant's trial testimony and his statements made before police officials, police transcripts were to be read in cuurt. While it was up to the court to choose the most believable verson, ${ }^{130}$ judges generally tended to give the benefit of the doubt to testimony supplied by police interrogators. ${ }^{131}$ The commission had suggested a complete reversal of this practice. The Minister of Justice, the Ittorney General and the highest judicial officer now insisted, however, that improvements in recording techniques used by the police would be sufficient; no change of the law was required. ${ }^{132}$

126. This German slang term denotes partiinost'.

127. 11 N.J. 493 (1957). See also Benjamin, Die Schoeffenwahlen 1958, Neues Deutschland, Oct. 31, 1957, p. 1. For official comment on the Thirtieth Plenary Session, see Der Kanpf gegen bucrgerliche Ideologie und Revisionismus, 12 EINHEIT ZEITSCHRIFT FUER Theorie und Prasis des wissenschaftlichen Sozialisarus 129, 136 (1957).

128. Address by Walter Ulbricht at the Thirty-third Plenary Session of the SED Central Committee, Neues Deutschland, Oct. 20, 1957, special section (Beilage), p. 30.

129. For some official statements, see Benjamin, Dic dialektische Einheit von Gesetslichkeit und Parteilichkeit durchsetzen!, 12 N.J. 365 (1958); Streit, Fuer einen tetueis Arbeitsstil in der Justiz, 12 N.J. 368 (1958).

130. Police officers who have taken pretrial testimuny generally are not heard by the court and are not cross-examined. Circumstances surrounding pretrial interrogations can hardly be elicited within the normal procedural framework.

131. This had been brought out by many DDR lawyers. See Benjamin, Fragen des Beweisrechts in Strafprozess, in Deutsches Institut fuer Rechtwissensceaft, 84, 87, 174 (1957).

132. Editorial, Ergebnisse der Disklussion ueber die Amwendung der STPO, 11 N.J. 601,605 (1957). 
The upshot a few months later was a group of amendments which, among other things, finally defined the offenses catalogued in, or just shoved under the umbrella of, article 6 . One commentator, writing in the period of reaction against the 1956 "revisionism," insisted that the amendments add rothing fundamentally new and do not put the organs of criminal repression before terra incognita. ${ }^{133}$ Despite its political coloring, this evaluation, with one exception, is generally correct. The touchy problem of flight from the DDR, an issue disagreeable both from the viewpoint of the prestige of the regime and for the dilemma caused by the need to encourage the lost sheep's return into the fold, is now resolutely solved by treating both the fact of flight and most cases of incitement to flee the DDR as punishable crimes against the State. In line with SED boss Ulbricht's injunction that leaving the DDR connotes treason against the interest of the people, unauthorized emigration from the DDR is now subject to a maximum of three years' imprisonment. ${ }^{134}$ Furthermore, agents who, in serving a "mercenary" military establishment or recruiting for business enterprises, induce people to flee are liable to penal servitude. Whoever by promises, threats, or misrepresentations incites a youthful person, an apprentice, or a person with special professional qualifications to leave the DDR is liable to a minimum of six months' imprisonment. ${ }^{135}$ With a touch of involuntary humor, the commentator adds that incitement grounded on family or sexual relations is not encompassed by the criminal law. ${ }^{130}$

133. Renneberg, Die nenen Strafbestimmungen zum Schutze der deutsihen demakraischen Republik, 12 N.J. 7 (1958). The decisions of the High Court on state security matters during the first half of 1958 bear out this contention. While substituting the nomenclature of the Penal Code Amendment Act-officially styled the milder law and hence retroactively applicable-for article 6 of the constitution, the court has in no instance found it necessary to change the sentence as determined by the lower court, on the basis of article 6. See, for example, the latest reported Jehovah's Witnesses case, where the espionage and agitators provisions of $\$ \$ 14$ and 19 of the P.C.A.A. are substituted for article 6 of the constitution. High Court Decision of Feb. 28, 1958, 12 N.J. 248 (1958).

134. Amendment to Passport Law \$ 8, [1957] G.B.D.D.R. 650 (Dec. 11). Cesare Beccaria, in chapter 32 of his essay on Crime and Punishment, uses the example of the uselessness of penal provisions against emigration in order to show the similar foolishness of attempts to punish suicide. While part of his argument is dated-the subject of the eighteenth-century Hapsburg monarchy did not foresee the effectiveness and ruthlessness of the twentieth-century totalitarian regimes-his insistence on the difficulty arising from punishing returning "criminals" still applies to modern totalitarian governments which, like many of their mercantilist predecessors, want to induce able-bodied and skilled nationals to return to the fold.

135. Penal Code Amendment Act of Dec. 11, 1957, § 21, [1957] G.B.D.D.R. 643. The vice president of the High Court recently gave a rather extensive interpretation of both the meaning of inducement to flee and an aggravated case of inducement. His understanding of the needs of "the present class struggle situation" would qualify inducement by Jehovah's Witnesses or an evangelical academy under $\$ 21(1) .1$. Jahn, Einige Fragen der Verleitung zum Verlassen der DDR, 12 N.J. 840, 843 (1958).

136. Renneberg, Die neuen Strafbestinnmungen zum Schutze der deutschen demokratischen Republik, 12 N.J. 7, 11 (1958). 
In most other respects, the amendments restate pre-existing concepts employed to interpret the nomenclature of article 6. Each theoretical term is carefully conceived to allow full latitude for the ever-shifting needs expressed in changing "points of concentration."

The material concept of the offense is now a construct formally enshrined in the DDR criminal law. ${ }^{137}$ Characteristic of the state of mind with which the authorities approach the job of reformulating the state security legislation is the law governing illicit relations with organizations the DDR deems hostile. While the corresponding West German enactment, ${ }^{138}$ as construed in the celebrated John and Agartz cases, ${ }^{139}$ conditions punishability on a finding that the defendant has become an instrument of the hostile power, the DDR enactment omits such qualifications. As the official commentator makes quite clear, establishment of contacts for purely private purposes (registration, gathering of information) unrelated to any political rule or activity would come within its prohibition and would be punishable by a maximum of three years' imprisonment. ${ }^{140}$ Along with the typically totalitarian offense of "diversion"permitting a great number of common crimes to be identified as offenses against the state security-reappears the concept of "sabotage." It is defined as "impeding the work of governmental and affiliated organizations for the purpose of creating disturbances to destroy or undermine socialist reconstruction."141 Perpetrated by acts of commission such as misallocation of labor, or acts of omission such as negligence in the exercise of official duties, sabotage is punishable with penal servitude. Espionage, treason, diversion and sabotage may in a number of specifically enumerated circumstances be punished with penal servitude for life, or with death. The new formulation will, as East German comments emphasize, exclude these extreme penalties in all other cases. ${ }^{142}$ This "advantage" is obliterated by the fact that among the aggravated cir-

137. Penal Code Amendment Act $\$$ \&. See text accompanying notes 105-07 supra. Mforeover courts are now at liberty to pass conditional sentences of a maximum of two years' imprisonment; they also may substitute "public censure," either alone or in conjunction with a fine for short-term prison sentences. P.C.A.A. \$\& 1-6. However, these provisions, issued during a period of sharp reaction against all forms of revisionism and liberalism, are officially interpreted in a rather restrictive manner. The High Court and administration are concerned to narrow down their field of application and oppose lower court practices of resorting to them routinely (considered a manifestation of the presently much-vituperated practice of "sentencing with a discount"). See Renneberg, Die neuen Strafarten in der Praxis unserer Gerichte, 12 N.J. 372 (1958).

138. Penal Code $\$ 100 \mathrm{~d}(2)$.

139. Otto John, Dec. 22, 1956, 2 St. E 15/56 (Bundesgerichtshof 3. Strafsenat) ; Viktor Agartz, Dec. 13, 1957, 1 St. E 8/57 (Bundesgerichtshof 3. Strafsenat), 2 Hochrerrat und Staatsgeführdung, Urteile des Bundesgerichtshofs 77, 132 (1958) (John); id. at 187, 220 (Agartz).

140. Penal Code Amendment Act $\$ 16$; Renneberg, Die nenten Strafbestinmungen zum Sichutze der deutschen demokratischen Republik, 12 N.J. 7,9 (1958).

141. Penal Code Amendment Act $\$ \$ 22,23$.

142. Penal Code Amendment Act $\$ 24$; Lekschas, Das STEG-das mildere Gesetz im Verhacltnis zu Art 6 der Verfassung, 12 N.J. 84 (1958). 
cumstances allowing the imposition of these penalties are found two definitions sufficiently vague to constitute a blank check: violation of a relationship of trust and the existence of a period of increased danger for the DDR. ${ }^{143}$

Difficulties of interpretation have arisen in applying the penal code amendments to hostile propaganda. Criteria are lacking for distinguishing between mere defamation of the state ${ }^{144}$ and state-endangering threats and agitation. ${ }^{145}$ At the height of the early 1958 movement against revisionism, penal policy veered sharply toward finding calculated hostility and intended, or at least probable, sedition in critical behavior that merely expressed personal displeasure. ${ }^{140}$ More recently, the counsel of moderation has prevailed. The evaluation sheets that all courts must send to the Ministry of Justice in connection with any case involving questions of state security are being used to direct lower organs toward educational rather than penal treatment of the illtempered. ${ }^{147}$ In state-defamation cases, the courts have frequently denied the very punishability of the act because a prerequisite of the material concept of the offense-danger to the public at large-is missing. ${ }^{148}$ Or, the court may forego punishment in response to a fundamental change in the offender's attitude. ${ }^{149}$ Whether this policy is anything more than an attempt to rescue courts from swamps of trivialities in which friends of the regime or political neutrals ${ }^{16 n}$ become mired as often as do the more cautious agents of the class enemy cannot now be ascertained.

Conceivably, a new shift in tenor might be introduced under cover of the present campaign, initiated at the fifth SED congress, to emulate Soviet en'deavors toward all-embracing codification. ${ }^{151}$ But even if the codification campaign should signify that the high tide of the battle against revisionism is receding, the limited meaning of "formulated legal enactments" 152 within the

143. Penal Code Amendment Act $\$ 24(2)(d)-(e)$.

144. Defamation may incur no more than two years' imprisonment. Penal Code Amendment Act $\$ 20$.

145. Such crimes are punishable by imprisonment and, in aggravated cases, penal servitude. Penal Code Amendment Act $\$ 19$.

146. See cases cited note 66 supra.

147. Leim, Abgrensung der Hetze von der Staatsverlentmding, 12 N.J. 694 (1958).

148. High Court Judgment of Sept. 16, 1958, 12 N.J. 716 (1958) (complaints over delivery quotas and comparisons between attitudes of present agricultural authorities and behavior of former estate owners judged to be without damaging consequences anul to fall under $\$ 8$ of the Penal Code Amendment Act).

149. Judgments of the District Court of Dresden, Aug. 8, 1958, 12 N.J. 680 (1958). and of a local court in Riesa, Sept. 5, 1958, 12 N.J. 681 (1958).

150. See High Court Judgments of Sept. 5, 1958 (jokes hostile to regime, if reported disapprovingly to third person, held not to constitute state-endangering threat), and July 25, 1958 (importation of hostile periodicals by politically inactive individual does not establish presumption of intention to circulate such material among wider circles, and therefore held not punishable as state-endangering threat), 12 N.J. 717 (1958).

151. Buettner, Die Aufgabe der Gesetzgebung im Kampf umn den Sieg des Soxialismus in der Deutschen Demokratischen Republik, 7 StaAT und Rfcht 968 (1958).

152. Id. at 983. 
framework of a social order intent on both speedy institutional change and, more significantly, on alteration of the consciousness structure of its human material, is overwhelmingly important. So long as the ministries and the central apparatus of the party itself maintain their tight check on both prosecution and court work, ${ }^{168}$ the ebb and flow of changing slogans only show the extent to which the law remains at the disposal of party authority.

\section{CoNCLUSION}

In the superficially deceptive propensity of recent Communist legal doctrine to emphasize the normative element, ${ }^{104}$ an anxious maintenance of the closest possible relation between the legal norm and its creator and protector, the partycontrolled government machine, displays traits reminiscent of legal positivism. 'The resemblance is superficial, however. Under the East German system, the sovereign does not use a comprehensive and tightly knit body of law as his main channel of communication with the subjects, nor are the sovereign's orders necessarily issued by functionally competent authorities with a constitutionally defined jurisdiction. What the lower-level authorities have as mandatory guides may be a law, an administrative order, a resolution passed by a party body, a public speech delivered by a ranking official, an article published in a party publication, or a lecture on a fine point of doctrine. Such documents, only a few of which are officially classified as "normative acts," may either provide a high degree of specificity, or-more often-leave concretization to the executive agencies in charge. The lower-level office holder will be well advised to watch out constantly for reactions of the authorized primary interpreter in order to protect himself and assure obedience from his subordinates. Administrative objectives may be indicated by indirection, as in the criticism of operational mistakes or the designation of new "points of concentration."

This elastic system, which more often than not is at cross purposes with strict observance of legality, infuses a calculated element of specificity. It grants those

153. See Benjamin, Vom IV. zum V. Parteitag der Sosialistischen Einlicitspartei Dentscilands, 12 N.J. 437, 438 (1958). In her evaluation of the tasks set by the SED fifth party cungress, she reemphasizes the need for central direction of the courts' work. At any rate, the recent discussion in Russia of the locus and extent of court supervision and the ensuing reformulation of article 10 of the Principles of Criminal Procedure, though initially reported in 6 RECHTSWISSENSCHAFTLICHER INFORMATIONSDIENST 341 (1957), so far has found nu receptive ear in Eastern Germany. For an English version of this discussion, see Judicial ws. Erecutiz' Superzision Ozer the Couts, 10 The CuRRENT Digest of the Soviet P'RFss, No. 20, at 6 (1958). As recently as 1957, Minister of Justice Benjamin and other members of her ministry, citing the Czech example, have insisted on the need for continued direction of the courts by the Ministry of Justice, conditioned as it is by the concrete cconumic and political situation of East Germany, circumstances deemed to be at variance with those in the Soviet Union. Benjamin, Aktuelle Fragen der Gerichtsorganisation, in StaAt und Recht m Lichte lies grossen OkTober 189 (1957); Ostmann, Ueber die Organisation der Justizi'trixaltung, 11 N.J. 357 (1957).

154 David \& Hazard, 1 Le Droit Sovietique 78 (1954); Kelsen, The Communist THEORY OF LAW 129 (1955). 
in power the opportunity to single out for condemnation whichever specific approach they may deem inopportune. As instruments of command, the sovereign uses vituperation, criticism and exhortation as much as he does clear-cut orders or formalized laws setting forth generalized rules of conduct. The backfiring of individual decisions may always be blamed on lower echelons whose job it is to institutionalize and individualize policies laid down by a superior agency.

The formal law on the statute books is overgrown with numerous interpretative glosses of varying origin and age, yet as authoritative as the law itself. The judge-administrator must follow the latest signals from above. Simultaneously, he is expected to accommodate possible reactions of an undefined grassroots public, though not in the traditional way of striking a balance between norm requirements and the divergent interests of affected parties. Instead, his is the job of an errand boy ordered to deliver a letter and to bring back a receipt signed by the addressee. The receipt symbolizes the widely advertised "educational" function of the law. While there is no doubt that the government program will be carried out regardless of public volition, the official-no matter where he stands in the chain of command-is under the obligation to transform the citizens' passive obedience or recalcitrant obtuseness into cheerful cooperation.

The essence of "socialist legality," then, is guaranteeing that orders and signals are unfailingly observed at all subordinate levels. A measure of obedience may be ensured by establishing regular and permanent channels for implementation; this may even include procedures permitting the individual to react freely within such limits as suit the government's convenience and tally with the objectives to be obtained. But it is the objectives which count, not any degree of harmony between what the government wants and what grows out of institutional or legal positions accorded individuals or groups. When policies and official interpretations change, legality attaches to the new task at hand. Under no condition is it called upon to mediate between today's objectives of the sovereign and yesterday's expectations of the subject. At the service of a fixed policy rather than as a purveyor of societal equilibrium, legality represents a marriage between law and efficiency drive. It stands for the avoidance of lost motions; it becomes the government's whip to secure the attainment of top-priority goals.

Under such circumstances, what can be the nature of the law? No doubt, the SED and DDR government are fully aware of the beneficial effect guaranteed expectations have on all factors which make the individual maximally cooperative with his neighbors and the authorities. A great number of initiatives formalized in legal enactments might be adduced to show how laboriously the various $\mathrm{DDR}$ administrations have toiled to produce a maximum of such satisfactions. ${ }^{155}$ If the judge had adequate standing in the community to pro-

155. The quest for individual security was stressed in a recent attempt to bring some order into the rather chaotic business of norm creation. See Gentz, $Z$ u einigen Grundsactzon der Rechtsetzung, 12 N.J. 225-30 (1958). 
gress from individualizing these isolated norm complexes to independently deciding upon their respective priorities, he might help to create a longerrange balance between the claims of the individuals and those of the State. At the present stage of the DDR society, however, the problem simply does not present itself in such terms. The regime simultaneously assumes too many new ventures and faces or, at times, intentionally conjures up too many problems, to be able to allow anyone outside its political leadership to decide on the elements which should enter the momentary balance between the requirements of the regime and the allowable satisfactions of the citizenry. When the regime's major goals have been fulfilled and its spiritual and social dominion safely anchored, the eternal guard against individual slackening may be relaxedand a referee allowed to mark points for both sides. Until that day, however, the judge remains a simple party servant correctly called by the regime itself "fuctionary of the apparatus of justice." Like his peers in other departments, he may become tired or too sympathetic with the stragglers in whom he recognizes his own image. Nevertheless, so long as the political front line is moving and the chow line forming at the rear, he falls in step. Thus, the variables in the guessing game called interpretation of the law reduce themselves rather drastically to the shifting policies of the Communist regime. 


\section{THE YALE LAW JOURNAL}

\begin{tabular}{lll}
\hline Volume 68 & MARCH 1959 & NuMber 4 \\
\hline
\end{tabular}

MITCHeI J. EZER

BURT W. GRIFFIN

JEROLD H. ISRAEL

Michael J. Nassau

Alan L. Wurtzel

Note and Comment

Editors

Matthew T. Adams

David Albenda

Alan Appelbaum

ROBERT L. BARD

Arthur J. Berk

Norman A. Bikales

BenjaMIIN W. Boley

Richard A. Brady

Peter D. Caldwell

JaMes M. EDwards

Eliezer EreLt

David R. Evans

J. EDWARD Fowler

Thomas N. Frohock

David Goldaerg
SYDNEY M. CONE, III

Editor-in-Chief

\author{
ROBERT J. EAGgelaran \\ JoRN K. MICNULTY \\ Article and Book \\ Review Editors
}

T. CECIL WRAY, JR.
Wanaging Editor

Bruce Montgoniery

Samiel Myers

Stuart B. Goldman

RICEARd S. HarRISON

NeIL S. HECHT

JACOB W. HeLLER

Alan M. Hoffman

Benjamin T. Hopkins, II

William A. Kass

Aron Katz

N. Herschel Koblenz

EUGENE I. LAMBBERT

J. D. LAMBERT

IRVING I. LESNICK

JOHN C. MCGUIRE

Frederick W. McNabb, JR. Patricia W. Weingerg

Stephen MaNn
J. ALEXANDER ONDERDONK

Alan D. PEKelNer

Charles J. Prentiss

HERBERT ScHReIber

BARRY SidMaN

Richard Lauder Sutton

Colin C. TaIt

JoHN W. VANDOREN

GILBERT PAUL Verbit

HERBERT S. WANDER

DONALD P. WEFER

ROBERT L. WEINBERg
Marie McMahon
Business Secretary
DAVID BERLINER

Business Manager

\section{CONTRIBUTORS TO THIS ISSUE}

Grahad Hughes. B.A. 1948, M.A. 1951, Cambridge University; LI.B. 1950, University of Wales. Lecturer in Law, University of Hull, England, 1953-1956. Visiting Assistant Professor, Yale Law School, 1956-1958. Visiting Lecturer, New York University Law School, 1957-1958. Senior Fellow, Yale Law School.

Orto Krrch heImer. Dr. Jur. 1928, Bonn University. Chief, Central European Branch, Division of Research for Western Europe, Department of State, 1944-1955. Consultant, Rand Corporation, 1955-1956. Professor of Political Science, Graduate Faculty of Political and Social Science, The New School of Social Research, New York. 